\title{
LA DIGNIDAD HUMANA EN MÉXICO: SU GONTENIDO ESENCIAL A PARTIR DE LA JURISPRUDENCIA ALEMANA Y ESPAÑOLA*
}

\author{
HUMAN DIGNITY IN MEXICO: ITS ESSENTIAL CONTENT \\ FROM GERMAN AND SPANISH JURISPRUDENCE
}

\section{Rogelio LÓPEZ SÁNCHEZ*}

RESUMEN: De acuerdo con el criterio de la Suprema Corte de Justicia mexicana, la dignidad humana es el valor constitucional supremo del ordenamiento legal. A pesar de ello, existe un desarrollo primario en la legislación mexicana y en los precedentes jurídicos. Aún así, la dignidad humana ha sido reconocida en varias de las últimas decisiones de la Suprema Corte a fin de maximizar el contenido esencial de los derechos humanos. Por tal motivo, este trabajo analiza ambas perspectivas de la dignidad humana: la comparada y la internacional, principalmente la jurisprudencia alemana, española e interamericana.

Palabras clave: dignidad humana, contenido esencial, valores superiores.
ABSTRACT: According to Mexican Supreme Court of Justice legal criteria, human dignity is the supreme constitutional value in Mexican legal order. In spite of that fact, there is a primitive development in Mexican legislation and legal precedents. Even so, human dignity has been recognized by Supreme Court in several last decisions, in order to maximize human rights essential content. Therefore, this research paper analyzes both perspectives of human dignity: comparative and international, mainly german, spanish and Inter-American jurisprudence.

Keywords: human dignity, essential content, superior values.

* Artículo recibido el 16 de agosto de 2017 y aceptado para su publicación el 11 de octubre de 2017.

** Doctor en derecho constitucional. Profesor-investigador en la Facultad de Ciencias Políticas y Administración Pública de la Universidad Autónoma de Nuevo León. Miembro del Sistema Nacional de Investigadores, nivel, I. Contacto: rogeliolopez.com.mx..

Boletín Mexicano de Derecho Comparado, nueva serie, año L, núm. 151, enero-abril de 2018, pp. 135-173. 
SUMARIO: I. Introducción: objeto, sentido y función de la dignidad humana. II. Sentido(s) y significado(s) de la dignidad humana desde la hermenéutica jurídica. III. La inclusión de la dignidad humana en las Constituciones modernas: la experiencia comparada. IV. La dignidad humana como valor superior del ordenamiento jurídico: la óptica jurisprudencial en México. V. Conclusiones: hacia una imagen de persona humana desde la Constitución mexicana.

\section{INTRODUGGIÓN: OBJETO, SENTIDO Y FUNCIÓN}

\section{DE LA DIGNIDAD HUMANA}

No cabe duda que el sentido que se le otorga a la dignidad de la persona humana es uno de los más polisémicos, complejos y heterogéneos que existen en la filosofía política, la antropología, la ética, pero sobre todo en la ciencia jurídica. Desde la óptica historiográfica, el reconocimiento de las personas como seres autónomos, libres y con plena titularidad de derechos es una idea que inspira a la mayor parte de las Constituciones modernas. ${ }^{1}$ Sin embargo, el pleno reconocimiento universal de todos los seres humanos por igual ha sido un proceso lento y complejo, repleto de incertidumbres y claroscuros en la historia de la familia humana. Tal y como acertadamente expresa el filósofo Hans Jonás sobre su tesis denominada "heurística del temor", se puede afirmar:

Solamente la prevista desfiguración del hombre nos ayuda a forjarnos la idea de que - el hombre - ha de ser preservado de la desfiguración: y necesitamos que ese concepto se vea amenazado con formas muy concretas de amenaza, para, ante el espanto que tal cosa nos produce, afianzar una imagen verdadera del hombre. ${ }^{2}$

1 Donnelly, J., "Human Dignity and Human Rights", Universal Human Rights in the Theory and Practice, Princeton, Cornell University, 2013, pp. 120-160; Benda, Ernst, "The Protection of Human Dignity (Article 1 of the basic law)", en AA.VV., Fifty Years of German Basic Law the New Departure for Germany, Washington, American Institute for Contemporary German Studies, The Johns Hopkins University, 1999, pp. 35-46; Pascual Lagunas, Eulalia, Configuración jurídica de la dignidad humana en la jurisprudencia del Tribunal Constitucional, Barcelona, Bosch Editor, 2009; Carvajal Sánchez, Bernardo, El principio de dignidad de la persona humana en la jurisprudencia constitucional colombiana y francesa, Bogotá, Universidad del Externado de Colombia, 2005.

2 Jonás, Hans, El principio de responsabilidad (ensayo de una ética para una civilización tecnológica), Barcelona, Herder, 1995, p. 65.

Esta obra está bajo una Licencia Creative Commons

Atribución-NoComercial-SinDerivar 4.0 Internacional, IIJ-UNAM.

Boletín Mexicano de Derecho Comparado, núm. 151, pp. 135-173. 
Este constante temor de ser humillados es lo que nos vuelve más precavidos y atentos hacia cualquier clase de vejación o desprecio. No sólo la experiencia brutal y horrenda del holocausto nos ha marcado como especie para garantizar desde el derecho internacional, ${ }^{3}$ un estándar mínimo ético de derechos y garantías como la Declaración Universal de Derechos Humanos; a pesar de ello, los terribles acontecimientos posteriores en Camboya (1975-1979), Guatemala (80's), Bosnia (1992-1995), Ruanda (1994), Perú (1980-2000), han marcado también esta triste experiencia de deshumanización y exterminio, irónicamente, en nombre de la mejora racial, genética, e incluso hasta ética. ${ }^{4}$

El profesor Milton Lewis apunta cómo las visiones del mundo han modificado paulatinamente determinadas normas; por ejemplo, la esclavitud, que se consideró permitida, e incluso percibida como un signo de honor entre los dueños de los esclavos, "hasta que finalmente fue considerada una conducta inmoral, degradante, humillante y prohibida por las autoridades y el derecho internacional". ${ }^{5}$ Aún en pleno siglo XXI persisten prácticas como la tortura, la violación como táctica militar, la trata de personas, la exclusión social, la pobreza extrema, la explotación laboral, el trabajo forzado, que también son claros ejemplos de degradación. En este contexto, el concepto de dignidad esta aparejado con el de "no humillación" en sus distintas manifestaciones: directa o sutil, individual o grupal, simbólica o representativa. ${ }^{6}$ En este contexto, la dignidad de la persona tiene por objeto la no humillación y el reconocimiento del ser humano como tal. Es decir, el valor de las personas por el solo hecho de serlo, esta dignidad intrínseca, que no es otorgada por un estatus social, talentos o poderes, sino por el simple hecho de pertenecer a la especie hu-

3 "El derecho internacional, como todas las formas el derecho, es una práctica normativa en la cual los valores se orientan en torno al respecto y protección de ciertos derechos asociados con la dignidad de la persona humana". Capps, Patrick, Human Dignity and the Foundations of International Law, Portland, Hart Publishing, 2009, p. 273.

4 Glover, Jonathan, Humanity (A Moral History of the Twentieth Century), New Haven, Yale University Press, 2001, p. 207.

5 "A Brief History of Human Dignity: Idea and Application", en Lickiss, Norelle y Malpas Jeff (eds.), Perspectives on Human Dignity: A Conversation, Países Bajos, Springer, 2007, p. 93.

6 Neuhäuser, Christian, "Humiliation: The Collective Dimension", en Kaufmann, Paulus, Kuch Hannes et al. (eds.), Humiliation, Degradation, Dehumanization (Human Dignity Violated), Springer, Heidelberg, Library of Ethics and Applied Philosophy, vol. 24, 2011, pp. 21-36. 
mana. ${ }^{7}$ Por ello, coincido con la definición en sentido amplio que brindan algunos autores, como "entendimiento particular de cada cultura de la valía moral intrínseca a la persona humana y de sus propias relaciones políticas con la sociedad". 8

En las siguientes páginas me dedicaré a explicar el sentido que ha adquirido (desde la perspectiva occidental) el valor de la dignidad de la persona humana en las Constituciones modernas, desde la óptica de la hermenéutica jurídica. Enfocaré mi atención en la Constitución mexicana, basado en la experiencia comparada de España y Alemania, que será desarrollada en el tercer apartado, así como algunos de los precedentes más emblemáticos que le han dado sentido a este valor fundamental. El estudio sobre el origen y desarrollo de la dignidad en la jurisprudencia mexicana lo haré en la cuarta sección del presente estudio. En el país germano existe una prolija y abundante jurisprudencia que desarrolla la imagen de la persona humana a partir de la comprensión del artículo 1.1 de la Ley Fundamental de aquella nación. En la última parte de este capítulo expondré esta idea a manera de propuesta, que podría desarrollarse en la jurisprudencia mexicana.

\section{SENTIDO(S) Y SIGNIFICADO(S) DE LA DIGNIDAD HUMANA DESDE LA HERMENÉUTICA JURÍDICA}

Cuando se piensa en cómo proceder adecuadamente con una investigación sobre dignidad humana, viene a la mente la idea del círculo hermenéutico. ${ }^{9}$ Este esquema holístico iniciado por Schleiermacher, ${ }^{10}$ continuado por su discípulo Dilthey como un proceso de reconstrucción de las objetivaciones históricas; ${ }^{11}$ seguido en el siglo XX por Heidegger como proceso

7 Sulmasy, Daniel P., "Human Dignity and Human Worth", en Perspectives on Human Dignity..., cit., pp. 9-18; Kretzmer, D. and Klein, E. (eds.), The Concept of Human Dignity in Human Rights Discourse, Londres, The Hague-Kluwer Law International, 2002, pp. 9-17.

8 Howard, R., "Dignity, Community, and Human Rights", en An-Na'im (ed.), Human Rights in Cross-Cultural Perspective; A Request for Consensus, Philadelphia, PA-University of Pennsylvania Press, 1992, p. 83.

9 Lebech, Mette, On the Problem of Human Dignity: a Hermeneutical and Phenomenological Investigation, Wurzburg, Könighausen \& Neumann, 2009, p. 120.

10 Schleiermacher, F., Hermeneutics and Criticism and Other Writings, trad. y ed. Andrew Bowie, Cambridge University Press, 1998, p. 248.

11 Dilthey, W., Dos escritos sobre hermenéutica: el surgimiento de la hermenéutica y los esbozos para una crítica de la razón histórica, Madrid, Istmo, 2000, p. 67.

Esta obra está bajo una Licencia Creative Commons

Atribución-NoComercial-SinDerivar 4.0 Internacional, IIJ-UNAM.

Boletín Mexicano de Derecho Comparado, núm. 151, pp. 135-173. 
de intelección, ${ }^{12}$ y recuperado en la época moderna por Gadamer, como fusión de horizontes y mediación entre la historia efectual, ${ }_{13}^{13}$ servirán para comprender la evolución que ha tenido la dignidad a lo largo de las distintas épocas históricas, y así, poder dar sentido a uno de los valores más polisémicos por su dimensión espiritual, ética, filosófica, jurídica y hasta antropológica. A lo largo de la historia, las personas han necesitado del reconocimiento del otro para formar su identidad. En este contexto, uno de los principales exponentes del multiculturalismo ha desarrollado la tesis sobre la política del reconocimiento. Esta idea consiste en la formación de nuestra propia identidad "a partir del reconocimiento de los otros, o por falta de este, a menudo también, por el falso reconocimiento de otros", ${ }^{14}$ sufriendo, cuando sucede, la diferencia, discriminación y rechazo de la propia ciudadanía. Como ejemplos históricos se encuentra la segregación racial en los Estados Unidos de Norteamérica o la discriminación en contra de los homosexuales.

De esta manera, la identidad es algo que se construye como una experiencia compartida, mediante una red de relaciones humanas, tal y como explica la filósofa Hannah Arendt. Por consiguiente, la dignidad humana se encuentra condicionada a la posibilidad de aparecer ante otros y de ser reconocidos como seres únicos y singulares, mediante el habla y la actuación. ${ }^{15}$ Así, "el respeto por la dignidad humana implica el reconocimiento de mis semejantes o de las naciones semejantes a la mía, como súbditos, como constructores de mundos o como codificadores de un mundo común". ${ }^{16}$ La idea de reconocimiento es un elemento común en el proceso de comprensión sobre la singularidad y pluralidad del sujeto. Fichte fue

12 Heidegger, M., Being and Time, Oxford, Basil Blackwell, 1985, p. 128.

13 Gadamer, Hans-Georg, Verdad y método I, trad. de Ana Agud Aparicio y Rafael de Agapito, Salamanca, Ediciones Sígueme, 1997, p. 360; Verdad y método II, Salamanca, Ediciones Sígueme, 2005, p. 68.

14 Taylor, Charles, "La política del reconocimiento", en El multiculturalismo y "la política del reconocimiento", textos introductorios de Amy Gutmann, comentarios de Susan Wolf, Steven c. Rockefeller y Michael Walzer (ensayos de Jürgen Habermas y K. Anthony Appiah), México, Fondo de Cultura Económica, 2009, p. 68; Las fuentes del yo. La construcción de la identidad moderna, trad. de A. Lizón, Barcelona, Paidós, 1996.

15 Arendt, Hannah, La condición humana, Barcelona, Paidós, 2009, p. 203 y ss.; ¿Qué es la política?, Barcelona, Paidós, 1997; Jeffrey C., Isaac, "A New Guarantee on Earth: Hannah Arendt on Human Dignity and the Politics of Human Rights", The American Political Science Review, Washington, vol. 90, núm. 1, marzo, 1996, pp. 61-73.

16 Arendt, Hannah, Los orígenes del totalitarismo, Madrid, Taurus, 1998, p. 367. 
uno de los primeros en introducir la idea del reconocimiento mutuo en torno a la construcción de la singularidad. ${ }^{17}$ Asimismo, Hegel implantó más adelante la idea del reconocimiento intersubjetivo como condición de realización de la integridad, dignidad y libertad. ${ }^{18}$ Por consiguiente, reconocimiento e identidad son dos elementos indispensables para comprender el sentido y el significado asignado a la persona y a la dignidad de la misma. Tal y como afirma Peces-Barba, "la dignidad humana es un horizonte, un deber ser que se puede realizar en el dinamismo de la vida humana, siempre limitadamente, siempre condicionado históricamente y temporalmente en el plazo de nuestra existencia". ${ }^{19}$ Es posible reconstruir la dignidad humana a partir de las tradiciones, que serán sintetizadas a continuación (elaboración propia):

\begin{tabular}{|c|c|c|c|c|c|}
\hline \multicolumn{7}{|c|}{ LA IDEA DE LA DIGNIDAD HUMANA } \\
\hline & $\begin{array}{c}\text { Época } \\
\text { clásica }\end{array}$ & $\begin{array}{c}\text { Época } \\
\text { medieval }\end{array}$ & Renacimiento & Ilustración & Modernidad \\
\hline $\begin{array}{c}\text { Proceso de } \\
\text { retroalimen- } \\
\text { tación entre } \\
\text { las tradiciones }\end{array}$ & $\longrightarrow$ & $\longrightarrow$ & $\longrightarrow$ & $\longrightarrow$ \\
\hline Idea & $\begin{array}{c}\text { Autonomía } \\
\text { impuesta } \\
\text { siguiendo } \\
\text { pautas } \\
\text { morales y } \\
\text { sociales }\end{array}$ & $\begin{array}{c}\text { Imagen } \\
\text { de Dios }\end{array}$ & $\begin{array}{c}\text { El hombre } \\
\text { como } \\
\text { "milagro" }\end{array}$ & $\begin{array}{c}\text { Ser } \\
\text { autónomo }\end{array}$ & $\begin{array}{c}\text { Persona } \\
\text { humana } \\
\text { (universalidad) }\end{array}$ \\
\hline
\end{tabular}

17 Gottlieb Fichte, Johann, Fundamento del derecho natural según los principios de la doctrina de la ciencia, Madrid, Centro de Estudios Constitucionales, 1994, p. 34, § 18 y 19; del mismo autor: Ética o El sistema de la doctrina de las costumbres según los principios de la doctrina de la ciencia, Madrid, Akal, 2005, p. 310; Kinlaw, C. Jeffery, "Practical Rationality and Natural Right: Fichte and Hegel on Self-Conception within a Relation of Natural Right", en Breazeale, Daniel and Rockmore, Tom (eds.), Fichte, German Idealism, and Early Romanticism, Países Bajos, Fichte-Studien-Supplementa, Sociedad Internacional, Johann-Gottlieb-Fichte, vol. 24, 2010, pp. 207-226.

18 Hegel, G. W., Fenomenología del espiritu, México, Fondo de Cultura Económica, 1966, p. 373.

19 Peces-Barba Martínez, G., La dignidad de la persona desde la filosofia del derecho, Madrid, Dykinson-Instituto de Derechos Humanos Bartolomé de las Casas, 2004, p. 49.

Esta obra está bajo una Licencia Creative Commons

Atribución-NoComercial-SinDerivar 4.0 Internacional, IIJ-UNAM.

Boletín Mexicano de Derecho Comparado, núm. 151, pp. 135-173. 
Esta revista forma parte del acervo de la Biblioteca Jurídica Virtual del Instituto de Investigaciones Jurídicas de la UNAM

\begin{tabular}{|c|c|c|c|c|c|}
\hline $\begin{array}{c}\text { Concepción } \\
\text { antropológica }\end{array}$ & $\begin{array}{c}\text { Ser político } \\
\text { Ciudadano } \\
\text { del mundo }\end{array}$ & $\begin{array}{c}\text { Naturaleza } \\
\text { humana } \\
\text { mala }\end{array}$ & $\begin{array}{c}\text { Naturaleza } \\
\text { humana } \\
\text { buena }\end{array}$ & $\begin{array}{c}\text { Naturaleza } \\
\text { humana } \\
\text { buena, pero } \\
\text { corruptible }\end{array}$ & $\begin{array}{c}\text { Concepción } \\
\text { antropológica } \\
\text { abierta, plural } \\
\text { e inclusiva }\end{array}$ \\
\hline
\end{tabular}

La dignidad humana tiene sus orígenes en el pensamiento clásico, principalmente en las ideas del estoicismo, que formulan la idea de humanidad. Existen cuatro elementos indispensables que se trasladan a la modernidad para entender este concepto: "el Cuidado de sí", el "Sapere aude", el "Carpe diem" y la noción de "Ciudadano del mundo". ${ }^{20}$ La mayor parte de estas categorías serán recuperadas en la modernidad para reconstruir la figura de la dignidad. Para los filósofos pertenecientes al periodo socrático, la idea de dignidad humana se encuentra íntimamente relacionada con la concepción antropocéntrica del ser humano. Para Platón, la dignidad debe ser conseguida mediante el conocimiento verdadero; para ello, es necesario el dominio de nosotros mismos a través de las virtudes, como enseñaba su maestro Sócrates. ${ }^{21}$ Posteriormente, el autor de La República expone que el individuo debe producir por sí mismo el saber y la virtud como conocimiento (sabiduría, valentía, templanza y justicia), e igualmente rechaza la democracia ateniense, demostrando su apego por un modelo de jerarquía de las naturalezas humanas. ${ }^{22}$ En este contexto, el modelo educativo griego se basaba en la formación espiritual y técnica de las cualidades morales o virtudes, pero desde una especia de nobleza o elite, excluyendo a esclavos y demás estratos sociales. ${ }^{23}$

Por otra parte, Aristóteles defiende una visión antropocéntrica del hombre destinado a luchar para establecerse en el mundo, incluso, sin

20 Peces-Barba Martínez, G., "Introducción”, en Pele, Antonio, La dignidad humana. Sus orígenes en el pensamiento clásico, Madrid, Instituto de Derechos Humanos Bartolomé de las Casas-Universidad Carlos III-Dykinson, 2010, p. 21.

21 Platón, Diálogos II (Gorgias, Menéxeno, Eutidemo, Menón, Crátilo), Madrid, Gredos, 1987, p. 275; Hegel, G. W. F., Lecciones sobre historia de la filosofia, t. II, México, Fondo de Cultura Económica, 2002, p. 41; Koyré, Alexandre, Introducción a la lectura de Platón, Madrid, Alianza Editorial, 1966, p. 23.

22 Pele, Antonio, La dignidad humana. Sus orígenes en el pensamiento clásico..., cit., p. 78; Hegel, G. W. F., Lecciones sobre la filosofia de la historia universal (edición abreviada que contiene: Introducción general y especial-mundo griego y romano), trad. de José Gaos, Madrid, Tecnos, 2005, pp. 420 y ss.

23 Jaeger, Werner, La Paideia: los ideales de la cultura griega, México, Fondo de Cultura Económica, 1996, p. 21. 
importarle que la naturaleza humana sea viciada o no, pugnando así por encontrar un método para alcanzar mejor su esencia $;{ }^{24}$ en tal sentido, las virtudes éticas (valentía, moderación, mansedumbre, magnificencia) son necesarias para dominar la parte irracional del hombre, y son adquiridas a través de la costumbre o el hábito. ${ }^{25}$ Cicerón, Séneca y Marco Aurelio estuvieron fuertemente influenciados por el estoicismo griego; en la obra de Cicerón existen varias citas de la obra Obligaciones del hombre, del filósofo Panecio de Rodas (estoicismo medio), quien a su vez había fusionado el pensamiento socrático; por tal motivo, las virtudes defendidas por esta corriente filosófica se referían a las cuatro partes de la honestidad: justicia, sabiduría, fortaleza y templanza. ${ }^{26}$ Igualmente, en este periodo podemos encontrar una gran riqueza en la estimulación de la idea de autonomía individual y voluntad humana. ${ }^{27}$

Uno de los estudios más completos sobre las virtudes del hombre con relación al Estado se encuentra en el famoso De officiis (Sobre los deberes, o De oficios) de Cicerón. Ésta es una de las obras más representativas y de contenido filosófico profundo dirigidas al ámbito de la función pública. ${ }^{28}$ En ella están plasmadas las cualidades del hombre: prudencia, justicia y fortaleza. Dicho lo anterior, la filosofía griega, así como su difusión por los pensadores romanos como Cicerón, sirvió para desarrollar las virtudes como parte fundamental de la civitas en la República de Roma, derivado de la idea de polis griega, el ser humano pasaba de ser un animal político a un animal social. ${ }^{29}$ La idea de humanitas de Cicerón sigue tres direcciones: "la primera, como antropología, es relativa a la consideración del hombre como ser racional, social y miembro de la ciudad. La segunda se refiere a una cultura específica que se nutre de la influencia griega. La tercera, por

24 Pele, Antonio, La dignidad humana. Sus orígenes en el pensamiento clásico..., cit., p. 205.

25 Aristóteles, Ética nicomaquea..., libro VI, cit., 1228b, pp. 467 y ss.

26 Daraki, María y Romeyer-Dherbey, Gilbert, El mundo helenístico: cínicos, estoicos y epicúreos, Madrid, Akal ediciones, 1996, p. 44; Gil Bera, Eduardo, Pensamiento estoico, Barcelona, Edhasa, 2002, p. 23; Capelleti, Ángel J., "Introducción”, en Los estoicos antiguos, Madrid, Gredos, 1996, p. 18; Cicerón, M. T., Los deberes y las paradojas de los estoicos, Madrid, Iberia, 1961; Salles, Ricardo, Los estoicos y el problema de la libertad, México, UNAM, Instituto de Investigaciones Filosóficas, 2009, p. 58.

27 Pele, Antonio, La dignidad humana. Sus orígenes en el pensamiento clásico..., cit., p. 310.

28 Cicerón, "Los oficios", en Obras completas de Marco Tulio Cicerón, Madrid, Librería y Casa Editorial Hernando, 1924, t. IV, libro primero, p. 54.

29 Sartori, Giovanni, La política, México, Fondo de Cultura Económica, 2003, p. 204.

Esta obra está bajo una Licencia Creative Commons

Atribución-NoComercial-SinDerivar 4.0 Internacional, IIJ-UNAM.

Boletín Mexicano de Derecho Comparado, núm. 151, pp. 135-173. 
fin, se dedica a la benevolencia". ${ }^{30}$ Asimismo, el filósofo romano identifica a la piedad y a la clemencia como virtudes a quienes se encargan de administrar justicia. ${ }^{31}$ Por último, Séneca aporta una defensa de la interioridad del ser humano como defensa a la dignidad del individuo. En síntesis, en la antigüedad prevalecerá una idea de dignidad impuesta sobre el cumplimiento de ciertas pautas morales y sociales, convirtiéndose, por consiguiente, en una categoría de ciudadanía excluyente y opuesta al valor de igualdad de todos los seres humanos. ${ }^{32}$

Con la entrada en la Edad Media, la idea de dignidad humana será heterónoma, el pensamiento humanista medieval en autores como san Agustín, Gregorio de Nicea y Tomás de Aquino, quienes fusionarán la concepción antropológica del hombre con Dios, integrándolo en el alma y la razón humana. ${ }^{33}$ Aunado a ello, el pensamiento eclesiástico fomentará una visión antropocéntrica pesimista del ser humano, de desprecio hacia la identidad corporal y de su razón, ya que su dignidad se encontrará "derivada de la imagen de Dios, proyectada sobre las criaturas". ${ }^{34}$

Este paradigma sobre la miseria del ser humano se agotará durante la entrada del humanismo renacentista. En este contexto, la dignitas hominis

Deriva de la excelencia del ser humano que se manifiesta empíricamente en la "admiración" que provoca. Este rasgo pretende romper definitivamente con el pesimismo antropológico. El individuo humano tiene las características del propio Dios, convirtiéndose en un "gran milagro"... La existencia humana no es sinónima de penitencia y de sumisión. El presente y lo inmanente no están absorbidos por lo trascendente y lo divino. La vida humana es una prolongación de la voluntad divina, y la actividad racional, técnica y moral del ser humano participa de esta misma voluntad superior. ${ }^{35}$

En esta época aparecerán pensadores de la talla de Giovanni Pico della Mirandola, quien en su más importante obra construirá un concep-

\footnotetext{
30 Pele, Antonio, La dignidad humana. Sus orígenes en el pensamiento clásico..., cit., p. 457.

31 Cicerón, "Los oficios", cit., pp. 55 y 56.

32 Pele, Antonio, La dignidad humana. Sus orígenes en el pensamiento clásico..., cit., p. 703.

33 Pele, Antonio, "Modelos de la dignidad del ser humano en la edad media", Derechos y Libertades, II época, núm. 21, junio de 2009, pp. 149-185.

34 Peces-Barba Martínez, G., La dignidad de la persona..., cit., p. 27.

35 Pele, Antonio, El discurso de la dignitas hominis en el humanismo del renacimiento, Madrid, Dykinson, 2012, p. 48.
} 
to de dignidad a partir de la libertad autocreadora del hombre. ${ }^{36}$ Por su parte, Giordano Bruno desarrollará una idea de autonomía individual, libre de los dogmas religiosos. ${ }^{37}$ Asimismo, aparecerán en escena dos pensadores claves para la construcción de una idea de dignidad en los pueblos de América. Se trata de Montaigne y Bartolomé de las Casas, quienes defenderán una idea de igualdad entre los hombres $;^{38}$ el primero, a partir de una "humanidad natural secularizada" criticando al "buen salvaje", conquistador del nuevo mundo, ${ }^{39}$ mientras que el fraile dominico criticará la idea de la superioridad cultural de los conquistadores. ${ }^{40}$

Finalmente, una de las concepciones más reconocidas y empleadas en la tradición jurídica occidental es la idea ilustrada de Kant sobre la dignidad del hombre. El filósofo de Könisberg concibe al derecho como una "obligación universal de todos, de actuar conforme a la libertad de todos según las leyes universales". ${ }^{41}$ En este sentido, elabora el imperativo categórico desde la razón práctica sobre la dignidad de la siguiente manera:

36 Discurso sobre la dignidad del hombre, México, UNAM, 2004, p. 14.

37 Giordano, Bruno, Sobre el infinito universo y los mundos (iniciación filosófica), Buenos Aires, Aguilar, 1981, p. 26.

38 Pelé, Antonio, "Montaigne y Las Casas, dos defensores de la dignidad humana”, en AA. VV. Estudios en homenaje al profesor Gregorio Peces-Barba, Madrid, Dykinson, vol. 3, 2008, pp. 959-974.

39 Dice el pensador francés: "creo que nada hay de bárbaro ni de salvaje en esas naciones, según lo que se me ha referido; lo que ocurre es que cada cual llama barbarie a lo que es ajeno a sus costumbres. Como no tenemos otro punto de mira para distinguir la verdad y la razón que el ejemplo e idea de las opiniones y usos de país en que vivimos, a nuestro dictamen en él tienen su asiento la perfecta religión, el gobierno más cumplido, el más irreprochable uso de todas las cosas", De Montaigne, Michel, Ensayos (libro I), París, 1912 , p. 159.

40 Beuchot, M., Los fundamentos de los derechos humanos en Bartolomé de las Casas, Barcelona, Anthropos, 1994, p. 32; en igual sentido, puede leerse en Vitoria lo siguiente: "Queda, pues, firme todo lo dicho, que los bárbaros eran, sin duda alguna, verdaderos dueños pública y privadamente, como los cristianos, y que tampoco por éste título pudieron ser despojados de sus posesiones, como si no fueran verdaderos dueños, los príncipes y las personas particulares". Vitoria, Francisco, Derecho natural y de gentes, título original: Relectiones theologicae, R. P. Fr. Franciscini Victorae, Buenos Aires, Emecé Editores, 1946, pp. 160 y 161.

41 Kant, Immanuel, Principios metafisicos del derecho, trad. de G. Lizárraga, Madrid, Librería de Victoriano Suárez, 1873, p. 44. Según Kant, el principio universal del derecho consiste en que "Una acción es conforme a derecho (recht) cuando permite, o cuya máxima permite la libertad del arbitrio de cada uno coexistir con la libertad de todos según una ley universal. Kant, Immanuel, La metafisica de las costumbres, Madrid, Tecnos, 2005, p. 39.

Esta obra está bajo una Licencia Creative Commons

Atribución-NoComercial-SinDerivar 4.0 Internacional, IIJ-UNAM.

Boletín Mexicano de Derecho Comparado, núm. 151, pp. 135-173. 
Obra de tal modo que uses la humanidad, tanto en tu persona como en la persona de cualquier otro, siempre como un fin al mismo tiempo y nunca solamente como un medio... sujeto de todos los fines es todo ser racional, como un fin en sí mismo... ${ }^{42}$

Únicamente el hombre, y con él toda la criatura racional, es fin en sí mismo. Él es, efectivamente, el sujeto de la ley moral, que es santa, gracias a la autonomía de su libertad. ${ }^{43}$

Siguiendo este hilo conductor, con el pensamiento kantiano se cumple el proyecto humanista de la modernidad; la dignidad servirá de vehículo para legitimar los derechos de la personalidad, que tendrá como realización la libertad y la autonomía. ${ }^{44} \mathrm{El}$ proyecto del filósofo alemán consistirá en otorgar al Estado un papel preponderante: "desarrollar y fomentar el uso público de la razón". ${ }^{45}$ Esta tradición es recuperada por autores como Peces-Barba, quien manifiesta:

Es la dignidad que deriva de "nuestra condición relacional y de esa racionalidad que actúa a través de la ética pública, política y jurídica, para realizar el deber ser de nuestra dignidad desde la autonomía que supone la libertad de elección hasta la autonomía que alcanza la libertad moral, desarrollando nuestra capacidad racional, estética, comunicativa y convivencial" ${ }^{46}$

Otro de los proyectos más ambiciosos de reconstrucción de la dignidad a partir del concepto de autonomía y libertad kantiana es el del iusfilósofo Carlos Santiago Nino. El autor argentino propone una fundamentación de los derechos, entendidos desde la valoración de la autonomía de los individuos. Esta idea de dignidad de la persona se contrapondrá al

42 Kant, Immanuel, Fundamentación de la metafisica de las costumbres, trad. de Manuel García Morente, Santa Fe, Argentina, El Cid Editor, Colección de Clásicos en español, 2003, pp. 75 y 79 .

43 Kant, Immanuel, Crítica de la razón práctica, trad. de Manuel García Morente y E. Miñana y Villasagra, México, Porrúa, 2003, p. 170.

44 Pérez Luño, Antonio Enrique, "El papel de Kant en la formación histórica de los derechos humanos", en La filosofia de los derechos humanos, cap. XIII, vol. II, t. II, Siglo XVII, Historia de los derechos fundamentales, edición coordinada por Peces-Barba, M. Gregorio et al., Madrid, Dykinson, 2001, p. 452.

45 Pele, Antonio, "Kant, la ilustración y la domesticación del ser humano", Cuadernos Electrónicos de Filosofía del Derecho, Valencia, Universidad de Valencia, núm. 23, 2011, p. 441.

46 Peces-Barba, G., La dignidad de la persona..., p. 68.

Esta obra está bajo una Licencia Creative Commons Atribución-NoComercial-SinDerivar 4.0 Internacional, IIJ-UNAM. Boletín Mexicano de Derecho Comparado, núm. 151, pp. 135-173. 
principio opuesto al determinismo normativo. En este sentido, el Estado debe abstenerse de intervenir en el actuar en los planes de vida del sujeto, y debe limitarse a "diseñar las instituciones que faciliten la persecución individual de esos planes de vida y la satisfacción", procurando así el respeto al principio de inviolabilidad de la persona humana, "que proscribe imponer a los hombres contra su voluntad, sacrificios y privaciones que no redunden en su propio beneficio". ${ }^{47}$ La idea de respeto a la autonomía individual fue incorporada a la filosofía del derecho desde la década de los treinta del siglo pasado por iusfilósofos como Stammler y Radbruch. ${ }^{48}$ Siguiendo este hilo conductor, se puede afirmar que el concepto de dignidad humana no se agota en la garantía negativa de no interferencia, sino también a través del libre desarrollo de la persona; ${ }^{49}$ esto hace referencia a la concepción de libertad negativa y positiva elaborada por el profesor Isaiah Berlin, quien explica la libertad en sentido positivo, como la ausencia de obstáculos que impidan posibles decisiones y actividades, así como de obstrucciones en los caminos por los que un hombre decide andar. ${ }^{50}$

En este mismo sentido, Garzón Valdés defiende esta visión positiva a través de una dimensión social como punto de partida "para todas las reglas de convivencia humana que pretendan tener alguna justificación moral", que impulsa un mayor desarrollo y consolidación. ${ }^{51}$ Así, tras casi doscientos años de desarrollo constitucional, el sociólogo alemán Jürgen Habermas afirma que es precisamente la dignidad humana "la bisagra conceptual que ensambla la moral del respeto igualitario a cada sujeto con el derecho positivo y la producción jurídica democrática, de tal manera que de su interacción en circunstancias históricas favorables pudo resultar

47 Nino, Carlos, Ética y derechos humanos, Buenos Aires, Astrea, 1989, p. 204; del mismo autor: Introducción al análisis del derecho, Barcelona, Ariel, 2001, p. 421.

48 Radbruch, Gustavo, Introducción a la filosofia del derecho, México, Fondo de Cultura Económica, 1951, pp. 181-190; Stammler, Rudolf, Tratado de filosofía del derecho, Madrid, Reus, 1930, p. 255.

49 Pérez Luño, A. E., Derechos humanos, Estado de derecho y Constitución, Madrid, Tecnos, 2005, p. 324.

50 Berlin, Isaiah, "Dos conceptos sobre libertad", en Cuatro ensayos sobre la libertad, versión de Julio Bayón, Madrid, Alianza Editorial, 1998, pp. 215-280.

51 Garzón Valdés, E., Tolerancia, dignidady democracia, Lima, Universidad Inca Garcilaso de la Vega, Nuevos Tiempos, Nuevas Ideas, Fondo Editorial, L. Lavado (ed.), 2006, p. 260; “Cuál es la relevancia moral del concepto de dignidad humana?”, en Positivismo jurídico, México, Fontamara, 2006, pp. 19 y 20.

Esta obra está bajo una Licencia Creative Commons

Atribución-NoComercial-SinDerivar 4.0 Internacional, IIJ-UNAM.

Boletín Mexicano de Derecho Comparado, núm. 151, pp. 135-173. 
un orden político basado en los derechos fundamentales". ${ }^{52}$ A pesar de lo expuesto con antelación, la dignidad humana se enfrenta hoy en día ante agudas críticas, tales como la inutilidad, la ambigüedad, el etnocentrismo, el eurocentrismo y el antropocentrismo, que encierra el mismo concepto. ${ }^{53}$ Incluso, existen destacados autores que han tratado de fundamentar la dignidad humana mediante la filosofía personalista, defendiendo la tesis sobre la desacralización de la vida humana, que "es susceptible de sufrimiento, pero no en mayor grado que a otros entes vivos y sensibles", ${ }^{54}$ tal y como ha sostenido Peter Singer en reiteradas ocasiones. ${ }^{55}$

Ante los distintos sentidos que puede adquirir la dignidad humana en el plano ontológico, ético y teológico, considero imprescindible formular algunas interrogantes desde la hermenéutica jurídica, que pueden servir de introducción para el siguiente apartado: ¿es la dignidad humana una cualidad etérea, difícil de aprehender en su esencia y contenido por el derecho constitucional, debido a la polisemia en significados? ¿Es la dignidad humana realmente el único fundamento primigenio y absoluto de los derechos humanos? ¿Cuál debe ser la imagen de la persona humana en las Constituciones modernas ante la complejidad y pluralidad de sentidos que se le otorga a la dignidad humana desde el plano ético, filosófico y espiritual? ¿Existe algún consenso universal mínimo o esta cuestión debe quedar abierta a dicha pluralidad de interpretaciones ante cada caso concreto?

\section{LA INCLUSIÓN DE LA DIGNIDAD HUMANA EN LAS CONSTITUCIONES MODERNAS: LA EXPERIENGIA GOMPARADA}

Es extraño que las primeras declaraciones de derechos, como la Americana, la francesa, o los documentos ingleses, no contengan alguna referencia o mención a la idea de dignidad de la persona humana, aun cuando esta

52 Habermas, Jürgen, "La idea de dignidad humana y la utopía realista de los derechos humanos", Anales de la Cátedra Francisco Suárez, 44, 2010, p. 111.

53 Pelé Illie, Antonio, "La dignidad humana: retos actuales", en Ansuátegui Roig, Francisco Javier et al. (coords.), Historia de los derechos fundamentales, vol. 4, t. 4: Valores, principios y derechos humanos, 2013, p. 43.

54 Torralba Roselló, Francesc, ¿Qué es la dignidad humana? (ensayo sobre Peter Singer, Hugo Tristram Engelhardt y John Harris), Barcelona, Herder, 2005.

55 Singer, P., Repensar la vida y la muerte (el derrumbe de nuestra ética tradicional), Barcelona, Paidós, 1997; Animal Liberation, Nueva York, Harper CollinsPubishers, 2002. 
categoría surge desde la antigüedad y persiste en nuestros días. No obstante, desde la perspectiva historiográfico-constitucional, ${ }^{56}$ esto se debe a una razón fundamental: se trata del constitucionalismo liberal, individualista, o estatalista, donde primaba una idea del hombre, de una ciudadanía excluyente, incluso de Estados que seguían permitiendo abiertamente la segregación racial o la esclavitud, y que irónicamente garantizaban con vehemencia a sus titulares la propiedad como derecho fundamental, incluso el dominio sobre otras personas.

En la mayor parte de los textos constitucionales liberales o ilustrados se habla del "hombre" como una categoría que va a definir la imagen que proyectan en la sociedad. Quedarían excluidos entonces muchos sectores sociales, como las mujeres ${ }^{57}$ los niños, los discapacitados, las personas de color, los homosexuales, los marginados; será el constitucionalismo de índole social que vendría a reivindicar a partir de mitades del siglo XX los derechos de estas minorías. Y, por supuesto, la dignidad humana será parte del consenso global en la Declaración Universal de los Derechos Humanos. Las Constituciones modernas aspiran a ser normativas. ${ }^{58}$ Desde las primeras décadas del siglo XX, autores han explicado la primera categoría como la limitación al Estado y al poder estatal frente al individuo, como garantía de las libertades y como "expresión de un ethos estatal que toma en serio al individuo... en su existencia política como corresponsable y codecisor, sin contemplarlo como un mero objeto de la política" ${ }^{59}$ Esta fuerza normativa de las Constituciones modernas consiste en la vigencia y aplicación de esos valores que el Constituyente ha decidido plas-

56 Fioravanti, Mauricio, Los derechos fundamentales. Apuntes de la teoría de las Constituciones, Madrid, Trotta, 2000, p. 50; Constitución, de la antigüedad a nuestros días, Madrid, Trotta, 2001, p. 163.

57 Como muestra de ello, se encuentra Mary Wollstonecraft, quien perdió la cabeza en la guillotina, en Francia, como consecuencia de la publicación de su Declaración de los Derechos de la Mujer y la Ciudadana. Wollstonecraft, Mary, Vindicación de los derechos de la mujer, trad. de C. Martínez, Valencia, Cátedra, 1996; Escudero Alday, Rafael, "Los derechos del hombre y de la mujer en Mary Wollstonecraft", en AA.VV., t. II, vol. II, Historia de los derechos fundamentales: La filosofia de los derechos humanos, dirigida por G. Peces-Barba Martínez y Eusebio Fernández García, Madrid, Instituto de Derechos Humanos "Bartolomé de las Casas"-Dykinson, 1998, p. 423.

58 Loewenstein, Karl, Teoría de la Constitución, Barcelona, Ariel, 1979, pp. 263 y ss.

59 Kägi, Werner, La Constitución como ordenamiento jurídico fundamental del Estado (investigaciones sobre las tendencias desarrolladas en el moderno derecho constitucional), estudio preliminar de Francisco Fernández Segado, Madrid, Dykinson, 2005, p. 79.

Esta obra está bajo una Licencia Creative Commons

Atribución-NoComercial-SinDerivar 4.0 Internacional, IIJ-UNAM.

Boletín Mexicano de Derecho Comparado, núm. 151, pp. 135-173. 
mar en el texto fundamental como superiores, sin ánimo de ser lírica o poesía constitucional. ${ }^{60}$

En este contexto, la aparición por primera vez de la dignidad humana como principio en las Constituciones lo encontramos en los textos de la posguerra, principalmente en los Estados federales alemanes, como Baviera, Bremen, Hesse y Sarre; y a nivel nacional, con la Ley Fundamental de Bonn en 1949. ${ }^{61}$ Por supuesto, prosiguieron Estados como Suecia (1975), Grecia (1975), Portugal (1976), España (1978), Suiza (1998), cuyos textos contemplan a la dignidad como base del orden político o dentro de sus catálogos de derechos fundamentales. ${ }^{62} \mathrm{~A}$ nivel internacional, la incorporación de la dignidad inicia con la Declaración Universal de los Derechos Humanos ${ }^{63}$ seguida por los textos de la Declaración Americana de los Derechos y Deberes del Hombre ${ }^{64}$ la Convención Americana de Derechos Humanos, ${ }^{65}$ así como la Convención Interamericana para Prevenir, Sancionar y Erradicar la Violencia contra la Mujer. ${ }^{66}$ Ahora bien, como aspecto relevante, me gustaría introducir dos textos clave para el análisis comparado en la presente sección. Se trata de la Ley Fundamental de Bonn, en sus numerales 1.1 y 2.1 (dignidad humana y libre desarrollo de la persona) ${ }^{67}$ así como la Constitución española de

60 Loewenstein, Karl, Teoría de la Constitución, trad. y estudio de la obra por Alfredo Gallego Anabitarte, 2a. ed., Barcelona, 1976, p. 150.

61 Igualmente, se puede referir como antecedentes previos, a las siguientes Constituciones: Weimar (1919, artículo 151.1), Irlanda (Preámbulo), Italia (1947, artículo 41). Starck, Christian, "Introducción a la dignidad humana en el derecho alemán", Anuario Iberoamericano de Fusticia Constitucional, Madrid, núm. 9, 2005, pp. 489-497.

62 Starck, Christian, "La dignidad del hombre como garantía constitucional, en especial en el derecho alemán", Furisdicción constitucional y derechos fundamentales, Madrid, Dykinson, 2011, p. 124.

63 Existen cinco referencias explícitas a la idea de dignidad humana, dos de ellas en el Preámbulo (primero y cuarto), y las tres restantes en los numerales 1, 22.2 y 23.3 (Seguridad social y derecho al trabajo).

64 Preámbulo y artículo XXIII.

65 Preámbulo, $\S 3$, artículos: 5.2 (integridad personal), 6o. (prohibición de esclavitud), 11.2 (honra).

66 Artículos 4o. (respeto y protección de los derechos de la mujer) y 80.

67 Artículo lo. Protección de la dignidad humana, vinculación del poder estatal a los Derechos Fundamentales] 1. La dignidad del hombre es inalienable. Es deber de todas las autoridades del Estado su respeto y protección; Artículo 2o. [Libertad de acción, libertad de la persona] (1) Toda persona tiene el derecho al libre desarrollo de su personalidad 
1978, en su artículo $10,{ }^{68}$ en ambos textos hay una mención a la dignidad humana como fundamento del orden político y la paz social, incluso en el texto alemán prevalece una idea cosmopolita y universal.

La Ley Fundamental de Bonn ha sido objeto de un envidiable desarrollo jurisprudencial mediante la introducción al constitucionalismo de figuras como imagen del hombre, no instrumentalización de la persona humana, orden objetivo de valores. ${ }^{69}$ No cabe duda que su desarrollo jurisprudencial tiene mucha relación con el grado de avance como civilización, al haber superado los traumas éticos, políticos y culturales que dejó el periodo nazi, y reivindicar como sociedad ante el mundo, que nunca volvería a ocurrir la vulneración y desprecio por la dignidad de la persona. El constitucionalismo alemán se ha convertido en uno de los máximos estandartes de aquel país, ${ }^{70}$ incluso abriendo este proceso de comprensión de derechos a la sociedad alemana. ${ }^{71} \mathrm{El}$ Tribunal Constitucional de aquel país ha sido uno de los más activos en Europa en cuanto al desarrollo de la dignidad humana se refiere. Tal y como he expuesto con antelación, la imagen del hombre (Menschenbild) en la Ley Fundamental de Bonn es una de las contribuciones de la doctrina jurisprudencial alemana al derecho constitucional. En una de las decisiones más emblemáticas, el Tribunal Constitucional de aquella nación (caso "Objeción de conciencia", frente a la obligación de defender a la patria, en la ley militar) se ha referido a

siempre que no viole los derechos de otra ni atente contra el orden constitucional o la ley moral.

68 La dignidad de la persona, los derechos inviolables que le son inherentes, el libre desarrollo de la personalidad, el respeto a la ley y a los derechos de los demás son fundamento del orden político y de la paz social.

69 Benda, Ernst, "Art. 1o. Abs. 1 GG als objektive Rechtsnorm und Grundrecht”, en Gefahrdungen der Menschenwïrde, Bayern, Westdeutscher Verlag, p. 10.

70 Barber Crosby, Margaret, The Making of a German Constitution (A Slow Revolution), Nueva York, Berg, 2008, p. 7; Zaiden Benvindo, Juliano, On the Limits of Constitutional Adjudication (Deconstructing Balancing and Fudicial Activism), Heidelberg, Springer, 2010, p. 31; Stern, Klaus, Verfassungsgerichtsbarkeit zwischen Recht und Politik, Bayern, West deutscher Verlag, p. 7; Vanberg, Georg, The Politics of Constitutional Review in Germany, Cambridge, Cambridge University Press, 2005, p. 111 ; Zacher, Hans F., Social Policy in the Federal Republic of Germany (The Constitution of the Social), Heidelberg, Springer-Ministro Federal del TrabajoArchivo Federal, 2013, p. 13.

71 Häberle, Peter, "Verfassungsgerichtsbarkeit in der offenen Gesellschaft", en Van Ooyen, Robert C. y Möllers, Martin H. W. (eds.), Das Bundesverfassungsgericht im politischen System, Heidelberg, Springer, Verlag für Sozialwissenschaften, pp. 35-46.

Esta obra está bajo una Licencia Creative Commons

Atribución-NoComercial-SinDerivar 4.0 Internacional, IIJ-UNAM.

Boletín Mexicano de Derecho Comparado, núm. 151, pp. 135-173. 
la doble dimensión de la dignidad en sentido individual y colectivo, de la siguiente manera:

La imagen del hombre contenida en la Ley Fundamental no es de un individuo autocrático; sino la que tiene en relación con su comunidad, sin que por ello se vea menoscabada su propia sustantividad. Esto se desprende, en particular, a partir de una visión en conjunto de los artículos 1o., 2o., 12, 14, 15, 19 y 20 de la Ley Fundamental... El individuo debe asumir aquellos límites que, para cultivar y fomentar la vida en común, imponga el legislador a su libertad de acción, dentro de los márgenes de lo exigible y siempre que se garantice la autonomía de la persona. ${ }^{72}$

En adición a lo anterior, defiende quien fuera profesor de teoría del Estado de la Universidad de Tubinga, Günther Dürig, y autor de la fórmula de no instrumentalización de la persona (Objektformel):

...el enunciado de derecho fundamental sobre la dignidad humana ha sido históricamente producto de la reacción en contra de un colectivismo totalitario en la vida constitucional alemana... pero el presupuesto del hombre en la Ley Fundamental (que debe ser la medida de todo el derecho) tampoco corresponde al otro extremo que se considera en el sentido liberal, clásico del siglo XIX, con el carácter autónomo e independiente de cada acción del individuo. ${ }^{73}$

De esta forma, sostiene Benda, "no sólo se rechazan las concepciones individualistas del liberalismo clásico, sino también las tentaciones colectivistas; renunciando a solicitudes extremas, se busca una línea intermedia". ${ }^{74}$ En este contexto, el Tribunal alemán se pronunció cuando decidió sobre la ilegalización del Partido Comunista, recordando la experiencia durante el periodo nazi, aludiendo a la condición del hombre como objeto de un ente colectivo. ${ }^{75}$ Regresando a la fórmula de no ins-

72 BVerfGE vol. 12, p. 45 (Ley de Objeción de Conciencia I) (Primera Sala, 20 de diciembre de 1960), $\S 19$.

73 Dürig, Günter, "Comentarios al artículo 1o. de la Ley Fundamental de Bonn”, en Maunz, Theodor y Dürig G. (eds.), Günter et al., Grundgesetz (Kommentar), vol. 1, artículos 1o. al 12, München, C. H. Beck'sche Editor, 1993, pp. 23 y 24, § 46.

74 Benda, Ernst, "Dignidad humana y derechos de la personalidad", en Benda, Ernst et al., Manual de derecho constitucional, Madrid, Marcial Pons-Instituto Vasco de Administración Pública, 1996, p. 119, § 5 .

75 BVerfGE vol. 5, p. 85 (caso Prohibición del Partido Comunista). 
trumentalización (Objektformel), construida por Dürig a partir de la reformulación del clásico imperativo kantiano, la categoría inicial ha ido en el sentido de no distinguir a los individuos por su valor moral. Sobre este aspecto, advierte puntualmente Benda:

El artículo 1.1 es válido para toda persona al margen de su grado moral de desarrollo, porque al menos idealmente toda persona está capacitada para su autorrealización moral. Está vedado distinguir entre los individuos en función de su presunto valor moral. El Estado no debe arrojarse el derecho a pronunciar un juicio absoluto sobre los individuos sometidos a su imperio. El Estado respetará al ser humano cuya dignidad se muestra en el hecho de tratar de realizarse en la medida de sus posibilidades. Incluso cuando tal esperanza parezca vana, bien porque la nieguen predisposiciones genéticas y sus metamorfosis, bien por propia culpa, nunca deberá el Estado emitir un juicio de valor concluyente y negativo sobre el individuo. ${ }^{76}$

Posterior a la segunda posguerra, la concepción elaborada por el distinguido jurista alemán Gunter Dürig ha sido clave para el proceso de comprensión de la dignidad de la persona en su dimensión objetiva y ontológica. Para el mencionado autor, la Ley Fundamental de Bonn contiene una "decisión axiomática eterna" en favor del contenido axiológico de los derechos fundamentales. En concreto, el artículo 1.1 (dignidad humana) es preexistente al derecho bajo una concepción iusnaturalista, y sin que este implique un reconocimiento de un derecho subjetivo como tal, sino como un valor interpretativo de todos los derechos fundamentales. ${ }^{77}$ $\mathrm{Al}$ respecto, el referido autor prescribe lo siguiente: "Un sistema de valores global resulta al mismo tiempo un sistema lógico-jurídico de derechos en el cual el valor superior se comporta respecto de los valores parciales como la norma jurídica superior respecto de las normas jurídicas inferiores". ${ }^{78}$

La dignidad de la persona humana es la cúspide del sistema constitucional, por medio de la cual se concretan contenidos de derechos de liber-

76 Benda, Ernst, "Dignidad humana y derechos de la personalidad", op. cit., p. 125, $\$ 16$.

77 Dürig, Günter, "Der Grundrechtssatz von der Menschenwürde: Entwurf eines praktischen Wertsystems der Grundrechte aus Art. 1o. Abs. I. in Verbindung mit Art. 19 Abs. II des Grundgesetzes", Archiv des öffentlichen Rechts, ZDB-ID, 4959, vol. 42, Tübingen, Mohr Siebeck, 1956, 2, p. 135.

78 Dürig, Günter, Escritos reunidos, 1952-1983, São Paulo, Editorial Saraiva Linha Direito Comparado, 2016, p. 87.

Esta obra está bajo una Licencia Creative Commons

Atribución-NoComercial-SinDerivar 4.0 Internacional, IIJ-UNAM.

Boletín Mexicano de Derecho Comparado, núm. 151, pp. 135-173. 
tad e igualdad (2 y 3 de la Ley Fundamental de Bonn). Fiel reflejo de lo anterior lo constituye la adopción de dicha teoría en el emblemático caso Lüth. ${ }^{79}$ Sin embargo, cabe destacar la posición antagónica de la teoría del orden de valores, pero en clave subjetiva, defendida por Rudolf Smend, a partir de la teoría de la integración, ${ }^{80}$ y que finalmente fuera adoptada también por el Tribunal Constitucional Federal Alemán por Konrad Hesse (discípulo de Smend), o bien la línea institucional seguida por Böckenförde, como crítico de la teoría objetiva. Finalmente, el estatus actual de la misma a partir de un concepto abierto y dinámico del sistema de valores a partir de la idea de Häberle como premisa antropológica y cultural del propio Estado constitucional. ${ }^{81}$

En tal sentido, destaca una fecunda interpretación constitucional por el tribunal germano del numeral 1 de la Ley Fundamental alemana con relación a casi todo el derecho, incluyendo el aspecto relacionado con las nuevas tecnologías y los dilemas que plantea la bioética. Haciendo una relación de las distintas áreas o temáticas del derecho sobre la aplicación del principio de la dignidad de la persona, se encuentran algunas de las siguientes resoluciones:

- Derecho penal (extradición, ${ }^{82}$ cadena perpetua, ${ }^{83}$ expulsión de extranjeros, ${ }^{84}$ prohibición de comunicaciones, ${ }^{85}$ informantes,${ }^{86} \mathrm{ob}$ jeción de conciencia, ${ }^{87}$ entre muchas otras).

- Derecho civil (libertad artística ${ }^{88}$ manifestación pública, ${ }^{89}$ libertad de prensa, honra, ${ }^{90}$ información, ${ }^{91}$ también, entre muchas otras).

79 BVerfGE, vol. 7, p. 198 (Fallo Lüth).

80 Smend, Rudolf, Constitución y derecho constitucional, trad. de José Ma. Beneyto Pérez, Madrid, CEC, 1985, pp. 62-106. (Esta edición contiene otros trabajos del constitucionalista alemán publicados en Staatrechtliche Abhandlungen en 1968).

81 Häberle, Peter, "Verfassungsgerichtsbarkeit in der offenen Gesellschaft", cit., p. 46.

82 BVerfGE, vol. 18, p. 112; BVerfGE 75, 1.

83 BVerfGE, vol. 145, p. 187, fj 2; BVerfGE 86, 288; BverfGE 72, 105.

84 BVerfGE, vol. 50, p. 166

85 BVerfGE, vol. 49, p. 24.

86 BVerfGE, vol. 57, p. 250.

87 BVerfGE, vol. 12, p. 45.

88 BVerfGE, vol. 30, p. 173 (caso Mephisto).

89 BVerfGE, vol. 7, p. 198 (Fallo Lüth).

90 BVerfGE, vol. 93, p. 266 (Los soldados son asesinos).

Esta obra está bajo una Licencia Creative Commons Atribución-NoComercial-SinDerivar 4.0 Internacional, IIJ-UNAM. Boletín Mexicano de Derecho Comparado, núm. 151, pp. 135-173. 
- Derecho administrativo (protección de datos personales ${ }^{92} \ldots$ ).

- Derecho social (Ley de ayudas a la inversión, ${ }^{93}$ procura existen$\left.\operatorname{cial}^{94} \ldots\right)$.

Igualmente, en este país han sido especialmente cuidadosos cuando se trata del desarrollo de nuevas tecnologías, tales como la manipulación de embriones para fines de investigación científica. ${ }^{95}$ Resumiendo esta posición, el profesor Christian Starck explica lo siguiente:

...desde el momento en que se produce la fusión de núcleos, el óvulo humano fecundado (embrión) pertenece a la especie humana. Su programa genético contiene la potencialidad del desarrollo como ser humano que prosigue si no interviene ninguna cesura. La identidad del embrión y la del niño nacido es una identidad genética, y no puede ser otra, porque, después, en el desarrollo de la persona intervienen otros factores de su alrededor que, en adelante, en el transcurso de la vida, van a fijar del todo la identidad modificable del individuo. Como en el óvulo fecundado existe vida humana individual, tiene efecto constitucional la protección de la dignidad y de la vida. ${ }^{96}$

En este sentido, Habermas se ha manifestado sobre los peligros de esta práctica manipuladora de la vida humana prenatal, en la posible degeneración sobre una desensibilización en el trato con la naturaleza humana; es decir, hacia una eugenesia liberal. ${ }^{97}$ A partir de lo anterior, existe la posibilidad de abogar a favor de ambas posturas. Una, que está encaminada al desarrollo de la investigación científica mediante la

91 BVerfGE, vol. 103, p. 44 (Videograbación de audiencias judiciales); 35, 202 (Asesinatos de soldados de Lebach).

92 BVerfGE, vol. 65, p. 1, § 155 (Ley Censo, y Microcenso: BVerfGE 27, 1).

93 BVerfGE, vol. 4, p. 7 \$29.

94 BVerGE, vol. 1, p. 97.

95 Ley de Protección a los Embriones, del 13 de diciembre de 1990 (BGBl. I S. 2746). Asimismo, puede consultarse en la jurisprudencia del Tribunal de Justicia de Comunidades Europeas: Oliver Brüstle contra Greenpeace eV., sentencia de la Gran Sala del 18 de octubre de 2011.

96 Starck, Christian, "Garantía de la dignidad humana en la práctica de la biomedicina”, Revista catalana de dret públic, núm. 36, 2008 (ejemplar dedicado a Los retos del derecho público frente a las ciencias de la vida), p. 105.

97 Habermas, Jürgen, El futuro de la naturaleza humana ¿hacia una eugenesia liberal?, Barcelona, Paidós, 2002, p. 42.

Esta obra está bajo una Licencia Creative Commons

Atribución-NoComercial-SinDerivar 4.0 Internacional, IIJ-UNAM.

Boletín Mexicano de Derecho Comparado, núm. 151, pp. 135-173. 
manipulación de embriones que tienen dignidad, y cuyo tratamiento merece respeto, debido a su potencialidad de convertirse en vida humana. No obstante, también existen del otro lado, razones morales de peso para defender la investigación científica, como los innovadores tratamientos para enfermedades incurables; es decir, que buscan proteger más vidas humanas. ${ }^{98}$

Por otra parte, se encuentra la jurisprudencia generada por el Tribunal Constitucional español sobre la dignidad de la persona humana, siguiendo una línea argumentativa muy similar a la del tribunal germano mediante la fórmula de no instrumentalización de la persona. Entre algunos de los criterios más relevantes se encuentran los siguientes: ${ }^{99}$

- La persona no puede ser patrimonializada; es sujeto, no objeto de contratos patrimoniales (STC 212/1996).

- El trabajador no puede ver subordinada su libertad mediante su consideración como "mero factor de producción" o "mera fuerza de trabajo" (STC 192/2003).

- La persona no puede ser, en cuanto tal, mero instrumento de diversión y entretenimiento (STG 231/1988).

- En el mismo sentido, la persona es convertida en mero objeto en los casos de agresión o acoso sexual (STC 224/1999).

- La dignidad impone que la asunción de compromisos u obligaciones tenga en cuenta la voluntad del sujeto, al menos cuando son de peculiar trascendencia, como la maternidad (STC 53/1985).

- La dignidad impone que sea reconocida al sujeto la posibilidad de participar en procesos judiciales en los que se le atribuyen graves responsabilidades penales, sin que pueda aparecer como mero objeto de dichos procedimientos (STC 91/2000).

Tal y como sostiene el profesor Fernández Segado, el numeral 10.1 de la Constitución española ha tenido una función hermenéutica para todas

98 Kaczor, Christopher, The Edge of Life Human Dignity and Contemporary Bioethics, Springer, Dordrecht, 2005, p. 5; Beyleveld, Deryck y Brownsword, Roger, Human Dignity in Bioethics and Biolaw, New York, Oxford University Press, 2001, p. 21; Nussbaum, Martha, "Human Dignity and Political Entitlements", en Lanigan, Barbara T. (ed.), Human Dignity and Bioethics, Nueva York, Nova Science Publishers, 2008, pp. 245-264.

99 Gutiérrez, Ignacio, Dignidad de la persona y derechos fundamentales, Madrid, Marcial Pons, 2005, p. 97. 
las normas ordinarias; es decir, como principio rector del ordenamiento jurídico. ${ }^{100}$ No obstante, también han surgido voces críticas que, a pesar de no negar el carácter de la dignidad como principio central del derecho público, por su enorme fuerza fundamentadora, ${ }^{101}$ también han apuntado hacia el empleo retórico y exagerado del término por el TCE en algunas de sus resoluciones.

...el Tribunal alude a la dignidad limitándose a señalar su relación con los derechos, y a resaltar la exigencia de respeto a la persona que comporta. Pero cuando desea pasar al caso concreto, olvida la dignidad y se aplica a determinar qué derecho en particular es objeto de discusión en el caso; y en aquellos casos donde no juega ningún derecho fundamental, el TC refuerza la invocación de la dignidad haciendo intervenir junto a ella, como si no fuese suficiente, otros principios de carácter material (caso del mínimo vital). ${ }^{102}$

Es importante señalar la íntima relación que tiene el libre desarrollo de la persona con el de dignidad, ${ }^{103}$ que ha servido de fundamento y soporte para otros derechos fundamentales. ${ }^{104}$ Sobre su concreción, el constitucionalista Bernal Pulido apunta:

...el libre desarrollo de la personalidad no debe ser entendido en un sentido perfeccionista, sino como un ámbito reservado al individuo para la toma de decisiones vitales... no corresponde al Estado, ni a la sociedad, sino a las

100 Fernández Segado, Francisco, "La dignidad de la persona como valor supremo del ordenamiento jurídico", en Estudios jurídico-constitucionales, México, UNAM, Instituto de Investigaciones Jurídicas, 2003, p. 22.

101 Serna, Pedro, "La dignidad de la persona como principio de derecho público", $D e^{-}$ rechos y Libertades. Revista del Instituto Bartolomé de las Casas, Universidad Carlos III de MadridInstituto Bartolomé de las Casas-BOE, II, (4), enero-junio 1995, p. 306.

102 Serna, Pedro, "Dignidad de la persona: un estudio jurisprudencial", Persona y Derecho: Revista de Fundamentación de las Instituciones Juridicas y de Derechos Humanos, núm. 41, 1999, p. 190 .

103 Tal es el caso del aborto en las resoluciones. TCE: 38/1994, 53/1985. O en relación con los derechos sociales. Sentencia de recurso de amparo 192/2003.

104 Asís Roig, Rafael de, "El artículo 10.1 de la Constitución española: la dignidad de la persona y el libre desarrollo de la personalidad como fundamentos del orden político y de la paz social", en Monereo Pérez, J. L. et al. (coords.), Comentario a la Constitución socioeconómica española, Granada, Comares, 2002, pp. 153-175.

Esta obra está bajo una Licencia Creative Commons

Atribución-NoComercial-SinDerivar 4.0 Internacional, IIJ-UNAM.

Boletín Mexicano de Derecho Comparado, núm. 151, pp. 135-173. 
propias personas decidir la manera como desarrollan sus derechos y construyen sus proyectos y modelos de realización personal. ${ }^{105}$

De esta manera, el libre desarrollo a la personalidad ha servido al TCE para ampliar e incluso crear nuevos derechos en el sistema constitucional español. Tal es el caso del derecho a la intimidad personal y familiar, ${ }^{106}$ o el caso de los derechos difusos o colectivos. ${ }^{107}$

La incorporación de la dignidad humana en las Constituciones modernas ocurre en un periodo histórico de reivindicación ética y moral de la persona humana. La positivación en los ordenamientos nacionales e internacionales se encuentra inspirada en la idea de una libertad autónoma; en algunas naciones como Alemania, este paradigma se ha convertido en un dogma dentro del derecho constitucional, llegando a ser considerado en sí mismo un valor, un principio, de categoría superior y fundante de la totalidad de los derechos fundamentales. Sin embargo, considero que esta construcción conceptual debe quedar abierta a los nuevos desafíos que plantea la realidad social, tal y como sucedió a partir de mitades del siglo pasado con los movimientos de lucha y reivindicación de los derechos de minorías, como las mujeres, los afroamericanos, los homosexuales, los discapacitados, entre otros. Por ello, considero pertinente revaluar propuestas como la de Häberle, quien la considera una premisa antropológicacultural de las Constituciones, "el cómo es que el ser humano llega a ser persona nos ofrece indicios de lo que es la dignidad humana... cómo se forma la identidad humana en una sociedad, y en qué medida puede partirse de un concepto válido entre culturas...". ${ }^{108}$

Siguiendo con esta idea, la dignidad, entendida como una categoría dialógica, inclusiva, plural y siempre perfectible, debe atender a los procesos discursivos en una sociedad multicultural, que exigen la reivindicación de su singularidad, así como la conformación de su identidad, como los

105 Bernal Pulido, Carlos, "El derecho al libre desarrollo de la personalidad", El derecho de los derechos (escritos sobre la aplicación de los derechos fundamentales), Bogotá, Universidad Externado de Colombia, pp. 247-254.

106 Sentencia TCE: 64/1986. Sentencia de recurso de inconstitucionalidad 290/2000.

107 Sentencia de recurso de amparo 16/2004; 119/2001. Sentencia de recurso de amparo 94/1999.

108 Häberle, Peter, El Estado constitucional, trad. de Héctor Fix-Fierro, México, UNAM, 2001, p. 169. 
pueblos originarios, y todas las minorías que reclaman su reconocimiento en Latinoamérica. En el caso mexicano, este valor ha sido elevado a un nivel superior en el ordenamiento jurídico, y fundante del resto de los derechos fundamentales; por ello, es necesario evaluar la pertinencia de ese discurso con los argumentos que los propios tribunales han invocado para considerar a este importante valor como tal, tema que será motivo del siguiente apartado.

\section{LA DIGNIDAD HUMANA COMO VALOR SUPERIOR DEL ORDENAMIENTO JURÍDICO: LA ÓPTICA JURISPRUDENGIAL EN MÉXICO}

Conforme al sistema de fuentes, históricamente la dignidad humana tiene su origen normativo en la reforma constitucional en materia educativa del 30 de diciembre de 1946, sobre el artículo 3o. de la carta magna. En aquella ocasión, se decidió incorporar a los fines de la educación básica una concepción de democracia como forma de vida, fomentando el aprecio por la dignidad de la persona. Se advierten del Diario de Debates los siguientes argumentos en la exposición de motivos:

No se puede concebir a un individuo que sea capaz de realizar íntegramente todos los fines de la vida, sino en relación y condicionado por las actividades y los hechos de los demás, porque llevamos la convicción arraigada en nuestra conciencia, de que cada hombre es una persona inviolable e igual a todas las demás, pero distinta de las cosas de las que se puede disponer libremente y de que esta inviolabilidad es inalienable. No podemos considerar a la Humanidad más que como un conjunto de hombres todos iguales, todos con los mismos derechos, todos mereciendo nuestro respeto y cuya dignidad es motivo también de nuestra consideración. ${ }^{109}$

Aquí se aprecia el dilema sobre el individualismo-colectivismo planteado por el tribunal alemán años más adelante, a través de una argumentación universalista de la persona humana, y del contexto que en aquel entonces vivía el mundo entero, como consecuencia del fin de la Segunda Guerra Mundial. A pesar de lo anterior, esta axiología no logró permear

109 Participación del diputado Fernando Moctezuma, Cámara de Diputados, Diario de Debates, XXXIX Legislatura, año III, periodo ordinario, 26 de diciembre de 1945.

Esta obra está bajo una Licencia Creative Commons

Atribución-NoComercial-SinDerivar 4.0 Internacional, IIJ-UNAM.

Boletín Mexicano de Derecho Comparado, núm. 151, pp. 135-173. 
efectivamente en los tribunales ni en las instituciones estatales, con el fin de lograr alcanzar la cultura constitucional deseada. Lo mismo sucede con la reforma al artículo 25, y la incorporación de la rectoría económica del Estado, donde se hace una escasa referencia en la exposición de motivos a la dignidad, relacionado con el concepto de sustentabilidad y desarrollo humano. ${ }^{110}$ Igualmente, es destacable la reforma constitucional que dio origen a la redacción actual del artículo 1o., último párrafo, de la Constitución federal, ${ }^{111}$ como consecuencia del proceso de reforma a la misma, en materia indígena (artículo 2o.). Es importante mencionar esta situación, debido a la enorme tensión generada en su momento, debido a los agudos acontecimientos en Chiapas por el Ejército de Liberación Nacional, desde los primeros días de 1994.

Esta reivindicación y lucha, de lo que el pensador Charles Taylor denominaría "política del reconocimiento", se hizo presente en aquella entidad federativa, causando conmoción a nivel mundial, por lo simbólico del movimiento (se trataba de una guerrilla). Naciones Unidas hizo un llamado al gobierno; ${ }^{112}$ pero quizá lo más sorprendente sería la lucha por la reivindicación de las demandas sobre los derechos de los pueblos indígenas (que se encontraban en el propio Convenio 169 de la OIT sobre el tema) después de cuatrocientos años de invisibilidad en el contexto político mexicano. En 2001, se alcanza un consenso legislativo medianamente aceptable, que logra plasmar en la Constitución (artículo

110 "Artículo 25. Corresponde al Estado la rectoría del desarrollo nacional para garantizar que éste sea integral y sustentable, que fortalezca la Soberanía de la Nación y su régimen democrático y que, mediante la competitividad, el fomento del crecimiento económico y el empleo y una más justa distribución del ingreso y la riqueza, permita el pleno ejercicio de la libertad y la dignidad de los individuos, grupos y clases sociales, cuya seguridad protege esta Constitución...". Al respecto:

Cámara de Diputados, Comisiones Unidas de Puntos Constitucionales, de Medio Ambiente y Recursos Naturales y de Estudios Legislativos, Diario de Debates, Procesos Legislativos, Dictamen y Discusión, México, D. F., a 22 de diciembre de 1998.

111 "Queda prohibida toda discriminación motivada por origen étnico o nacional, el género, la edad, las discapacidades, la condición social, las condiciones de salud, la religión, las opiniones, las preferencias sexuales, el estado civil o cualquier otra que atente contra la dignidad humana y tenga por objeto anular o menoscabar los derechos y libertades de las personas".

112 ONU, Comité para la Eliminación de la Discriminación Racial de la Organización de las Naciones Unidas, México, UN Doc A/52/18, anexo V de 122 (1997), 51 sesión, 15 de agosto de 1997, párr. 314. 
2o.), la autonomía de los pueblos indígenas; en este mismo paquete de reformas se introdujo una propuesta de inclusión al artículo lo., para quedar como actualmente se encuentra ahora. Lo anterior es sumamente importante, ya que el proceso dialógico de construcción sobre la imagen de la persona en la Constitución mexicana cambia, y se convierte en una categoría más incluyente y plural, reconociendo a los pueblos autóctonos en México. ${ }^{113}$

A partir de ese momento, el concepto de dignidad será objeto de múltiples interpretaciones en relación con el principio de igualdad y no discriminación, para incluir, como una especie de cajón de sastre, la interpretación del principio de igualdad formal y sustantiva en el derecho constitucional mexicano. Tan es así lo anterior, que la mayor parte de las resoluciones del Poder Judicial que hacen alusión a la dignidad de la persona se deben a la inclusión de esta figura en el numeral antes referido. ${ }^{114}$ El último proceso de consagración legislativa se encuentra en la reforma constitucional del 6 de junio de 2011, en materia de derechos humanos, donde se modifica el concepto de "individuo", del artículo lo. constitucional, por el de "persona", ${ }^{115}$ además de incorporar los instrumentos internacionales en materia de derechos humanos, que incluyen de manera expresa la dignidad de la persona.

113 G. senador Armando Méndez de la Luz, Gaceta, Senado de la República, Gaceta, dictamen y discusión, México, D. F., 25 de abril de 2001; Cámara de Diputados, Diario de los Debates, Segundo periodo de Sesiones Ordinarias, año l, núm. 17, V.I, 28 de abril de 2001.

114 Sentencia dictada por la Segunda Sala de la Suprema Corte de Justicia de la Nación en el amparo directo en revisión 881/2007, el 4 de julio de 2007, donde se invoca también el concepto de dignidad humana, pero se resuelve conforme al derecho de no discriminación; Sentencia dictada por el Cuarto Tribunal Colegiado en Materia Administrativa del Primer Circuito de la Suprema Corte de Justicia de la Nación dictada el 21 de abril de 2004 en el amparo en revisión 799/2003, que también resuelve apoyándose en el derecho a la no discriminación; Sentencia dictada por la Primera Sala de la Suprema Corte de Justicia de la Nación el 29 de septiembre de 2004 (amparo directo en revisión 988/2004).

115 "En los Estados Unidos Mexicanos todas las personas gozarán de los derechos humanos reconocidos en esta Constitución y en los tratados internacionales de los que el Estado Mexicano sea parte, así como de las garantías para su protección, cuyo ejercicio no podrá restringirse ni suspenderse, salvo en los casos y bajo las condiciones que esta Constitución establece.

Las normas relativas a los derechos humanos se interpretarán de conformidad con esta Constitución y con los tratados internacionales de la materia favoreciendo en todo tiempo a las personas la protección más amplia".

Esta obra está bajo una Licencia Creative Commons

Atribución-NoComercial-SinDerivar 4.0 Internacional, IIJ-UNAM.

Boletín Mexicano de Derecho Comparado, núm. 151, pp. 135-173. 
Esta revista forma parte del acervo de la Biblioteca Jurídica Virtual del Instituto de Investigaciones Jurídicas de la UNAM

El empleo de la dignidad de la persona humana como pauta hermenéutica para la comprensión de los derechos humanos en México tiene su origen en 2007, al declarar y reconocer a la dignidad humana y el libre desarrollo de la personalidad, junto a la igualdad, ${ }^{116}$ como los valores superiores del ordenamiento jurídico. Considero que las decisiones más emblemáticas que han orientado hermenéuticamente el concepto de dignidad humana se relacionan con los derechos de minorías, especialmente el caso de cambio de sexo ${ }^{117}$ y los matrimonios homosexuales. ${ }^{118}$

En la primera decisión (cambio de sexo), la SCJN orienta su interpretación en torno a la igualdad y autonomía de la persona, considerándola como un derecho fundamental y base de todos los demás derechos, haciendo una lista exhaustiva de los derechos no reconocidos por el texto fundamental, pero que derivan de ella, tales como el derecho a la vida, a la integridad física y psíquica, al honor, a la privacidad, al nombre, a la pro-

116 Considerando quinto de las sentencias judiciales relativas a los siguientes expedientes: Amparo en revisión 321/92. Pyosa, S. A. de C. V. 4 de junio de 1996, fj. 43. Ponente: Genaro David Góngora Pimentel; Amparo en revisión 1525/96. Jorge Cortés González. 8 de mayo de 1997, fj. 43. Ponente: Genaro David Góngora Pimentel.

117 Número de Registro: 165696. Reasignación SEXUAL. La NOTA MARGINAL EN EL ACTA DE NACIMIENTO DE LA SENTENCIA QUE OTORGÓ LA DEMANDA DE RECTIFICACIÓN DEL NOMBRE Y SEXO, CON LA CONSIGUIENTE PUBLICIDAD DE DATOS, VIOLA LOS DERECHOS FUNDAMENTALES DEL INTERESADO. Localización: [TA]; 9a. Época; Pleno; S.f.F. y su Gaceta; tomo XXX, diciembre de 2009; pág. 18. P. LXXII/2009; Número de Registro: 165695. ReASIGNACIÓN SEXUAL. LA SENTENCIA QUE NIEGA LA EXPEDICIÓN DE UNA NUEVA ACTA DE NACIMIENTO EN LA QUE SE REGTIFIQUEN LOS DATOS RELATIVOS AL NOMBRE Y SEXO DE UNA PERSONA TRANSEXUAL, ES INCONSTITUCIONAL (LEGISLACIÓN GIVIL DEL Distrito FEDERAL, VIGENTE ANTES DE LA REFORMA Publicada en la Gaceta Oficial del Distrito Federal el 10 De octubre de 2008). Localización: [TA]; 9a. Época; Pleno; S.f.F. y su Gaceta; tomo XXX, diciembre de 2009; pág. 18. P. LXIV/2009; Número de Registro: 165694. REASIGNACIÓN SEXUAL. NO EXISTE RAZONABILIDAD PARA LIMITAR LOS DERECHOS FUNDAMENTALES DE UNA PERSONA TRANSEXUAL, IMPIDIÉNDOLE LA ADEGUACIÓN DE SUS DOCUMENTOS DE IDENTIDAD, BAJO EL PRETEXTO DE PRESERVAR DERECHOS DE TERCEROS O EL ORDEN PÚBLICO. Localización: [TA]; 9a. Época; Pleno; S.J.F. y su Gaceta; tomo XXX, diciembre de 2009; pág. 19. P. LXXIV/2009.

118 MATRIMONIO ENTRE PERSONAS DEL MISMO SEXO. LA REFORMA AL ARTÍCULO 146 del Código Givil para el Distrito Federal, Publicada en la Gaceta OfiCIAL DE LA ENTIDAD EL 29 DE DICIEMBRE DE 2009, NO CONTRAVIENE EL CONTENIDO De la Constitución Política de los Estados Unidos Mexicanos. Tesis Aislada:

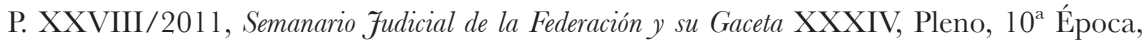
agosto de 2011, p. 877. Acción de inconstitucionalidad 2/2010.

Esta obra está bajo una Licencia Creative Commons Atribución-NoComercial-SinDerivar 4.0 Internacional, IIJ-UNAM. Boletín Mexicano de Derecho Comparado, núm. 151, pp. 135-173. 
pia imagen, al libre desarrollo de la personalidad, al estado civil y el propio derecho a la dignidad personal. ${ }^{119}$

En esta misma sentencia, el tribunal mexicano define al libre desarrollo de la persona como "el reconocimiento del Estado sobre la facultad natural de toda persona a ser individualmente como quiere ser, sin coacción ni controles injustificados, con el fin de cumplir las metas u objetivos que se ha fijado, de acuerdo con sus valores, ideas, expectativas, gustos, etcétera". ${ }^{120}$ En este razonamiento se encuentra una idea de libertad en sentido negativo y positivo. Por su parte, la decisión sobre la constitucionalización de los matrimonios homosexuales en el Distrito Federal, se trata de invocar como parámetro hermenéutico la decisión referida arriba: "La orientación sexual de una persona, como parte de su identidad personal, responde a un elemento relevante en su proyecto de vida, que incluye el deseo de tener una vida en común con otra persona de igual o distinto sexo".

Este criterio es empleado en otras decisiones relevantes sobre el matrimonio homosexual, en aquellas entidades federativas que no está reconocido como tal. La orientación y el sentido que se le otorga a estos principios son a partir de la igualdad y autonomía de la persona, invocando incluso precedentes de algunas cortes estatales de Estados Unidos, donde se razona con base en la idea de igualdad y no exclusión. ${ }^{121}$ Por otro lado, se encuentra la aplicación del principio de la dignidad, en relación con la procura existencial o vida digna. El sentido que se le otorga es un poco más claro en esta decisión, ya que lo relaciona con el valor de la solidaridad, "configurada como el requerimiento de que (sic) los individuos tengan como punto de partida condiciones tales que les permitan desarrollar un plan de vida autónomo, a fin de facilitar que los gobernados participen activamente en la vida democrática". ${ }^{122}$

119 DigNidAD HUMANA. El ORDEN JURÍDICO MEXICANO LA RECONOCE COMO CONDICIÓN Y BASE DE LOS DEMÁS DERECHOS FUnDAMENTALES. Tesis Aislada: P. LXV/2009, Semanario Fudicial de la Federación y su Gaceta, Novena Época, tomo XXXIII, enero de 2011, página 1707.

120 Derecho al Libre Desarrollo de la Personalidad. AsPectos QUe COMPRENDE. Tesis Aislada: P. LXVI/2009, Semanario Fudicial de la Federación y su Gaceta, XXX, diciembre de 2009, página: 7 .

121 Amparo en Revisión 581/2012 (Derivado de la Facultad de Atracción 202/2012), Primera Sala de la Suprema Corte de Justicia de la Nación, 5 de diciembre, 2012, pp. 16 y 17.

122 Derecho al Mínimo vital. Su ALCANCE EN RELACiÓn CON EL PRINCIPIO DE Generalidad tributaria. Tesis Aislada: 1a. X/2009, Semanario fudicial de la Federación y 
La referencia inmediata para entender a la dignidad humana en sentido ontológico e instrumental es el criterio jurisprudencial adoptado por la Primera Sala de la Suprema Corte mexicana, que en 2016 declaró expresamente la proyección o dimensión subjetiva de la misma a partir de su reconocimiento como derecho fundamental "por el cual se establece el mandato constitucional a todas las autoridades, e incluso particulares, de respetar y proteger la dignidad de todo individuo, entendida ésta - en su núcleo más esencial - como el interés inherente a toda persona, por el mero hecho de serlo, a ser tratada como tal y no como un objeto, a no ser humillada, degradada, envilecida o cosificada". ${ }^{123}$

Cabe indicar que el fundamento y base de la citada jurisprudencia fueron distintos asuntos en los cuales la Primera Sala del máximo tribunal mexicano resuelve temas civiles y administrativos relativos a la existencia digna (pensión alimenticia), ${ }^{124}$ no cosificación de la persona (contratos civiles), ${ }^{125}$ debido proceso en el procedimiento administrativo, ${ }^{126}$ invocando criterios jurisprudenciales de los años setenta de la Segunda Sala del Tribunal alemán sobre escuchas telefónicas (Sentencia BVerfGE 30, 1), ${ }^{127}$ a través de la invocación de la fórmula de no instrumentalización de la persona humana.

Este mismo criterio interpretativo sobre la dignidad humana será recurrente en asuntos similares, donde se trata de definir dogmáticamente a partir de conflictos de naturaleza civil por el Poder Judicial de la Federación, como "el origen, la esencia y el fin de todos los derechos humanos", ${ }^{128} \mathrm{o}$

su Gaceta XXIX, enero de 2009, p. 547; DereGHO AL MíNIMO VITAL. CONCEPTO, ALCANCES E INTERPRETACIÓN POR EL JUZGADOR. Tesis: I.4o.A.12 K (10a.); [TA]; 10a. Época; T.C.C.; S.7.F. y su Gaceta; libro XVII, febrero de 2013, tomo 2; pág. 1345.

123 Dignidad hUMANA. CONSTITUYe UNA NORMa JURÍDiCa QUE CONSAGRA UN DERECHO FUNDAMENTAL A FAVOR DE LAS PERSONAS Y NO UNA SIMPLE DECLARACIÓN ÉTICA. Localización: [J]; 10a. Época; la. Sala; Gaceta S.7.F.; libro 33, agosto de 2016; tomo II; pág. 633. 1a./J. $37 / 2016$ (10a.). Registro No. 2012363

124 Primera Sala de la SCJN: Amparo directo en revisión 2524/2015, párr. 50 y ss.; y amparo directo en revisión 230/2014.

125 Primera Sala de la SCJN: Amparo directo en revisión 6055/2014, tercer factor.

126 Primera Sala de la SCJN: Amparo directo en revisión 5327/2014, p. 16.

127 Primera Sala de la SCJN: Amparo directo en revisión 1200/2014, p. 21.

128 Dignidad humana. Definición. Tesis: I.5o.C. J/30 (9a.), Semanario fudicial de la Federación y su Gaceta, Quinto Tribunal Colegiado en materia civil del Primer Circuito, libro I, octubre de 2011, p. 1528. 
Esta revista forma parte del acervo de la Biblioteca Jurídica Virtual del Instituto de Investigaciones Jurídicas de la UNAM

como "una calidad única y excepcional a todo ser humano por el simple hecho de serlo...". ${ }^{129}$ En principio, se ha determinado que esta cualidad es inherente y exclusiva de las personas físicas. ${ }^{130}$ Para sistematizar esta gran labor hermenéutica que ha realizado el Poder Judicial de la Federación, se propone el siguiente esquema hermenéutico, dividido por temáticas, e indicando de manera sintética cuáles fueron los principales aportes de las decisiones.

- Derecho civil:

- Reconocimiento del matrimonio homosexual. Se reconoce el libre desarrollo de la personalidad como base y condición del ejercicio de la autonomía e igualdad de la persona, señalando que si una norma no establece un régimen jurídico igualitario de tratamiento en las entidades federativas, el mismo es discriminatorio, por razón de adoptar una preferencia sexual determinada. ${ }^{131}$

- Derecho al honor. Derivado de una demanda por daño moral, donde se reconoce el aspecto subjetivo o ético (dignidad de la persona) y derecho al honor e imagen frente a la libertad periodística (libertad de expresión), así como el ejercicio ponderativo para la solución de colisiones entre estos dos derechos fundamentales. ${ }^{132}$

129 Dignidad humana. Su naturaleza y COncePto. Tesis: I.5o.C. J/31 (9a.), Semanario Fudicial de la Federación y su Gaceta, Quinto Tribunal Colegiado en materia civil del Primer Circuito, libro I, octubre de 2011, p. 1529.

130 DERECHO A La Dignidad humana. Es CONNATURAL a LAS PERSONAS FÍsicas Y NO A LAS MORALES. Registro: 2002740; [TA]; Tesis: VI.3o.A.1 K, 10a. Época; T.C.C.; S.J.F. y su Gaceta; libro XVII, febrero de 2013, tomo 2; pág. 1344.

131 Número de Registro: 2006875. MATRIMONIO ENTRE PERSONAS DEL MISMO SEXO. NO EXISTE RAZÓN DE ÍNDOLE CONSTITUCIONAL PARA NO RECONOCERLO. Localización: [TA]; 10a. Época; la. Sala; Semanario Fudicial de la Federación 1a. CCLX/2014 (10a.); número de Registro: 2003282. EXCLUSIÓN DE LAS PAREJAS DEL MISMO SEXO DEL MATRIMONIO. EL HECHO DE QUE EXISTA UN RÉGIMEN SIMILAR PERO DISTINTO AL MATRIMONIO Y QUE POR ELLO SE LES IMPIDA EL ACGESO A LAS PAREJAS DEL MISMO SEXO ES DISCRIMINATORIO. Localización: [TA]; 10a. Época; la. Sala; S.f.F. y su Gaceta; libro XIX, abril de 2013, tomo 1; pág. 959. la. CIV/2013 (10a.); número de Registro: 2006878. NORMAS DISGRIMINATORIAS. NO ADMITEN INTERPRETACIÓN CONFORME Y EXISTE OBLIGACIÓN DE REPARAR. Localización: [TA]; 10a. Época; la. Sala; Semanario Judicial de la Federación 1a. CCLXI/2014 (10a.).

132 Número de Registro: 2005523. Derecho fUndAMENTAL AL HONOR. SU DIMENSIÓN SUBJETIVA Y OBJETIVA. Localización: [J] 10a. Época; la. Sala; Gaceta S.F.F.; libro 3,

Esta obra está bajo una Licencia Creative Commons

Atribución-NoComercial-SinDerivar 4.0 Internacional, IIJ-UNAM.

Boletín Mexicano de Derecho Comparado, núm. 151, pp. 135-173. 
Esta revista forma parte del acervo de la Biblioteca Jurídica Virtual del Instituto de Investigaciones Jurídicas de la UNAM

- Derecho al honor de las personas morales. Derivado de una demanda por daño moral interpuesta por el diario La fornada en contra de la revista Letras Libres, por asociar a este primero con grupos terroristas en España. En este sentido, se reconoce el derecho al honor (reputación) de una persona moral a partir de la dignidad en sentido objetivo. ${ }^{133}$

- Divorcio sin causa. Donde se invoca la dignidad humana y el libre desarrollo de la persona - en sentido de autonomía y libertad - para declarar inconstitucional las causales de divorcio. ${ }^{134}$

\section{- Derecho penal:}

- Individualización de penas. A partir de un amparo se invoca la fórmula de no instrumentalización de la persona humana (inculpado) en la imposición de penas en contra de adultos ${ }^{135} \mathrm{y}$ menores infractores. ${ }^{136}$

febrero de 2014, tomo I; pág. 470. 1a./J. 118/2013 (10a.); número de Registro: 171882. VIDA PRIVADA. El ARTÍCULO 1O. DE LA LEY SOBRE DELITOS DE IMPRENTA, AL PROTEGER EL HONOR Y LA REPUTACIÓN FRENTE A CUALQUIER MANIFESTACIÓN O EXPRESIÓN MALICIOSA, NO EXCEDE EL LÍMITE ESTABLECIDO POR EL ARTÍCULO 7O. DE LA CONSTITUCIÓN FEDERAL. Localización: [TA]; 9a. Época; la. Sala; S.f.F. y su Gaceta; tomo XXVI, julio de 2007; pág. 272. 1a. CXLVIII/2007.

133 Número de Registro: 2000082. Derecho FUndAMENTAL AL HONOR DE LAS PERSONAS JURÍDICAS. Localización: [TA]; 10a. Época; 1a. Sala; S.f.F. y su Gaceta; libro IV, enero de 2012, tomo 3; pág. 2905. 1a. XXI/2011 (10a.).

134 Número de Registro: 2005338. Divoraio. El ARTíCulo 175 Del Código FamiLIAR PARA EL ESTADO LIBRE Y SOBERANO DE MORELOS, AL EXIGIR LA DEMOSTRACióN DE DETERMINADA CAUSA PARA LOGRAR LA DISOLUCIÓN DEL VÍNCULO MATRIMONIAL, CUANDO NO EXISTE CONSENTIMIENTO MUTUO, ES INCONSTITUCIONAL AL RESTRINGIR EL DERECHO AL DESARROLlO DE LA PERSONALIDAD HUMANA. Localización: [TA]; 10a. Época; T.C.C.; Gaceta S.f.F.; libro 2, enero de 2014, tomo IV; pág. 3050. XVIII.4o.10 C (10a.); número de Registro: 2005339. Divorcio necESARIO. DEBE DEGRETARSE AUN GUANDO NO QUEDEN DEMOSTRADAS LAS CAUSALES INVOCADAS, TOMANDO EN CONSIDERACIÓN EL DEREGHO FUNDAMENTAL A LA DIGNIDAD HUMANA. Localización: [TA]; 10a. Época; T.C.G.; Gaceta S.F.F.; libro 2, enero de 2014, tomo IV; pág. 3051. XVIII.4o.15 C (10a.).

135 Número de Registro: 2005918. DeRECHO PENAL DE ACTO. RAZONES POR LAS CUALes la Constitución Política de los Estados Unidos Mexicanos SE Decanta POR DICHO PARADIGMA (INTERPRETACIÓN SISTEMÁTICA DE LOS ARTÍCULOS 1O., 14, TERGER PÁRRAFO, 18, SEGUNDO PÁRRAFO, Y 22, PRIMER PÁRRAFO). Localización: J]; 10a. Época; 1a. Sala; Gaceta S.F.F.; libro 4, marzo de 2014, tomo I; pág. 354. 1a./J. 21/2014 (10a.).

136 Número de Registro: 2004726. MEDIDA DE TRATAMIENTO EN INTERNACIÓN PARA ADOLESCENTES INFRACTORES. SI PARA SU ADECUADA APLICACIÓN EL JUEZ TOMA 
Esta revista forma parte del acervo de la Biblioteca Jurídica Virtual del Instituto de Investigaciones Jurídicas de la UNAM

- Ejecución de penas. Se desarrolla de manera argumentativa la fórmula de no instrumentalización de la persona humana (interno en un centro penitenciario) a partir del principio de legalidad, como la posibilidad de la suspensión condicional de la ejecución de la pena. ${ }^{137}$

- Derechos del inculpado. Caso San Salvador Atenco, derivado de graves violaciones a los derechos humanos cometidas durante el arresto de diversos manifestantes, donde la SCJN documentó violaciones graves a la dignidad humana - integridad personal de los detenidos - ${ }^{138}$

- Derechos del inculpado. Se establece la prohibición de tomar fotografias a personas que no han sido presentadas ante el Ministerio Público, a partir de una interpretación amplia de la dignidad humana y el derecho a la imagen. ${ }^{139}$

- Derechos del inculpado y violencia de género. Se reconoce a partir de la dignidad de la mujer en un proceso penal, la violación a su integridad cuando la autoridad es omisa en solicitar pruebas del estado mental de la indiciada (acusada en un proceso penal por homicidio) bajo la premisa de haber sufrido violencia de género. ${ }^{140}$

EN GONSIDERAGIÓN EL DIAGNÓSTICO TÉGNICO QUE LES FUE PRACTICADO, ELLO NO TRANSGREDE SU DERECHO A LA DIGNIDAD HUMANA, NI EL PRINCIPIO DE LEGALIDAD (LEGISLAGIÓN DEL DiSTRITO FEDERAL). Localización: [TA]; 10a. Época; T.C.C.; S.f.F. y su Gaceta; libro XXV, octubre de 2013, tomo 3; pág. 1825. I.9o.P.36 P (10a.).

137 Número de Registro: 2003779. SUSPENSIÓN CONDICIONAL DE LA EJECUCIÓN DE LA PENA. SI EL JUEZ PONDERA EL CONTENIDO DEL ESTUDIO DE PERSONALIDAD PRACTICADO AL INCULPADO PARA NEGARLE DICHO BENEFICIO, TRANSGREDE SU DERECHO A LA DIGNIDAD HUMANA, EL PRINCIPIO DE LEGALIDAD Y LA PROHIBICIÓN DE IMPONER PENAS INUSITADAS. Localización: [J]; 10a. Época; T.C.C.; S.f.F. y su Gaceta; libro XX, mayo de 2013, tomo 2; pág. 1649. I.9o.P.J/7 (10a.).

138 Número de Registro: 163167. Derechos a LA INTEGRIDAD PERSONAL Y AL TRATO DIGNO DE LOS DETENIDOS. ESTÁN TUTELADOS CONSTITUCIONAL Y CONVENCIONALMENTE Y SON EXIGIBLES INDEPENDIENTEMENTE DE LAS CAUSAS QUE HAYAN MOTIVADO LA PRIVACIÓN DE LA LIBERTAD. Localización: [TA]; 9a. Época; Pleno; S.f.F. y su Gaceta; tomo XXXIII, enero de 2011; pág. 26. P. LXIV/2010.

139 Número de Registro: 166037. ACTO DE MOLESTIA. LO CONSTITUYE LA TOMA DE FOTOGRAFÍAS A QUIENES NO TIENEN LA CALIDAD DE DETENIDOS O PRESUNTOS RESPONSABLES. Localización: [TA]; 9a. Época; la. Sala; S.f.F. y su Gaceta; tomo XXX, noviembre de 2009; pág. 401. 1a. CLXXXVIII/2009.

140 Número de Registro: 2005296. Prueba PERICIAL EN PSIQUiatría FORENSE. LA OMISIÓN DEL JUEZ DE ORDENAR OFICIOSAMENTE SU DESAHOGO CUANDO ADVIERTA

Esta obra está bajo una Licencia Creative Commons

Atribución-NoComercial-SinDerivar 4.0 Internacional, IIJ-UNAM.

Boletín Mexicano de Derecho Comparado, núm. 151, pp. 135-173. 
Esta revista forma parte del acervo de la Biblioteca Jurídica Virtual del Instituto de Investigaciones Jurídicas de la UNAM

- Derechos de la víctima. Se define el contenido esencial del derecho fundamental a la reparación del daño en un proceso penal a partir de la dignidad humana-derecho a la verdad, a la reparación material y moral. ${ }^{141}$

- Trabajo penitenciario. Estableciendo la prohibición del trabajo en los centros penitenciarios como trabajo forzado y recalificándolo como deber-derecho, y declarando inconstitucional el excluir de esto a los procesados por crimen organizado, ya que resultaba violatorio de la dignidad humana al cosificar a las personas por el solo hecho de encontrarse purgando una condena. ${ }^{142}$

- Derecho administrativo:

- Derecho a la intimidad. Se declaran inconstitucionales los requisitos excesivos para la determinación de actos administrativos desproporcionales tendientes a determinar la condición socioeconómica de una persona para garantizar su derecho a la salud, debido a que resultaban violatorios de la dignidad humana a partir del derecho a la intimidad. ${ }^{143}$

QUE LA MUJER ACUSADA DE HOMICIDIO SUFRIÓ VIOLENCIA DE GÉNERO POR LA VÍCTIMA, A EFECTO DE CONOGER EL ESTADO MENTAL DE AQUÉLLA AL MOMENTO DE LOS hechos, Viola derechos humanos (Legislación del Distrito Federal). Localización: [TA]; 10a. Época; T.C.C.; Gaceta S.J.F.; libro 2, enero de 2014, tomo IV; poág. 3189. I.9o.P.44 P (10a.).

141 Número de Registro: 2004579. RePARACiÓn DEL DAÑO DE LA VÍCTIMA U OFENDido DEL DELITO. CONTENIDO DE ESTE DERECHO FUNDAMENTAL (LEGISLAGión DEL ESTADO DE ChIAPAS). Localización: [TA]; 10a. Época; T.C.C.; S.f.F. y su Gaceta; libro XXIV, septiembre de 2013, tomo 3; pág. 2660. XXVII.1o.(VIII Región) 22 P (10a.).

142 Número de Registro: 2005110. Trabajo Penitenciario. Su Desarrollo debe ESTAR ERIGIDO SOBRE LA OBSERVANCIA Y EL RESPETO A LA DIGNIDAD HUMANA. LOcalización: [J]; 10a. Época; Pleno; Gaceta S.F.F.; libro 1, diciembre de 2013, tomo I; pág. 128. P./J. 34/2013 (10a.).

143 Número de Registro: 2006575. Instituto De SEguridad Social Del Estado DE MÉXICO Y Municipios. LA VERIFICACIÓN DE LA DEPENDENCIA ECONÓMICA DEL POSIBLE BENEFICIARIO DE SUS SERVICIOS, MEDIANTE EL ESTUDIO SOCIOECONÓMICO QUE SE LE PRACTIQUE CONFORME AL FORMATO APROBADO POR EL COMITÉ DE AFILIACIÓN, AL PERMITIR LA INVASIÓN DE ESPACIOS DE SU VIDA PRIVADA, VIOLA EL DERECHO FUNDAMENTAL A LA DIGNIDAD HUMANA. Localización: [TA]; 10a. Época; T.C.C.; Gaceta S.J.F.; libro 6, mayo de 2014, tomo III; pág. 2038. II.1o.A.14 A (10a.).

Esta obra está bajo una Licencia Creative Commons Atribución-NoComercial-SinDerivar 4.0 Internacional, IIJ-UNAM. Boletín Mexicano de Derecho Comparado, núm. 151, pp. 135-173. 
Esta revista forma parte del acervo de la Biblioteca Jurídica Virtual del Instituto de Investigaciones Jurídicas de la UNAM

- Derecho constitucional:

- Igualdad jurídica y no discriminación. La Primera Sala de la SCJN interpreta el artículo 24 de la Convención Americana sobre Derechos Humanos en relación con el 1o. constitucional, último párrafo, como condición inseparable de la dignidad humana, mediante el método hermenéutico de la proporcionalidad y razonabilidad. ${ }^{144}$

- Derechos de personas con discapacidad. Deriva de un asunto de naturaleza civil en materia de seguros, que restringía de manera desproporcional el derecho a la salud de una persona con discapacidad, a partir del concepto de dignidad en sentido ontológico y la superación del modelo de discapacidad establecido por las políticas de una empresa aseguradora. ${ }^{145}$

- Derecho social:

- Procura existencial - mínimo vital - Derivada de una interpretación ontológica de la dignidad humana contenida en el artículo 25 de la Constitución mexicana, al establecer el concepto de vida digna y solidaridad ante la desproporcionalidad de cargas impositivas de derecho fiscal y laboral que anulen su contenido esencial. ${ }^{146}$

144 Número de registro: 2012715. IGUALDAD JURÍDICA. INTERPRETACIÓN DEL ARTículo 24 De la Convención Americana sobre Derechos Humanos. Localización: []; 10a. Época; 1a. Sala; Gaceta S.f.F.; libro 35, octubre de 2016; tomo I ; pág. 370. 1a./J. 49/2016 (10a.).

145 Número de Registro: 2002519. Discapacidad. Presupuestos EN LA MATERIA QUE DEBEN SER TOMADOS EN CUENTA POR LOS OPERADORES DEL SISTEMA JURÍDICO MEXICANO. Localización: [TA]; 10a. Época; la. Sala; S.J.F. y su Gaceta; libro XVI, enero de 2013, tomo 1; pág. 633. 1a. VII/2013 (10a.).

146 Número de Registro: 159820. Derecho al MínIMO VITAL. SU CONTENIDO TRASCIENDE A TODOS LOS ÁMBITOS QUE PREVEAN MEDIDAS ESTATALES QUE PERMITAN RESPETAR LA DIGNIDAD HUMANA. Localización: [TA]; 10a. Época; Pleno; Gaceta S.f.F.; libro 1, diciembre de 2013, tomo I; pág. 136. P. VII/2013 (9a.); Número de Registro: 168160. DERECHO AL MÍNIMO VITAL. SU ALCANCE EN RELACIÓN CON EL PRINCIPIO DE GENERALIDAD TRIBUTARIA. Localización: [TA]; 9a. Época; la. Sala; S.f.F. y su Gaceta; tomo XXIX, enero de 2009; pág. 547. 1a. X/2009; Número de Registro: 172546. DeRECHO AL MÍNIMO VITAL. CONSTITUYE UN LÍMITE FRENTE AL LEGISLADOR EN LA IMPOSICIÓN DEL TRIBUTO. Localización: [TA]; 9a. Época; la. Sala; S.f.F. y su Gaceta; tomo XXV, mayo de 2007; pág. 792. 1a. XCVIII/2007.

Esta obra está bajo una Licencia Creative Commons

Atribución-NoComercial-SinDerivar 4.0 Internacional, IIJ-UNAM.

Boletín Mexicano de Derecho Comparado, núm. 151, pp. 135-173. 
- Derecho a la cultura. En sentido ontológico, se reconoce el derecho a la cultura como inherente de la dignidad de la persona humana en su plano individual y social. ${ }^{147}$

- Prestaciones laborales. Se incluye de manera dogmática como razonamiento en un juicio laboral debido al cálculo incorrecto de una prestación laboral, pero sin especificar ni argumentar el sentido hermenéutico de la misma, quizá desde el plano de procura existencial. ${ }^{148}$

- Salario mínimo. Se invoca la dignidad humana en un plano ontológico, al introducirla desde la perspectiva del concepto de vida digna contenido en el artículo 25 de la Constitución mexicana y prohibiendo, en consecuencia, los gravámenes excesivos al salario mínimo. ${ }^{149}$

Dicho lo anterior, la jurisprudencia mexicana ha incorporado tardíamente el principio de dignidad de la persona al sistema jurídico mexicano, a pesar de no estar inicialmente contemplado en la Constitución de 1917. En la materia penal existe un empleo reiterado de la fórmula de no instrumentalización a favor del inculpado y las víctimas del proceso penal. En el derecho civil se emplea como un principio expansor de los derechos inicialmente contemplados, tales como la imagen, el honor, la sexualidad. En el ámbito social, se incorpora el principio de procura existencial en relación con el de vida digna. Igualmente, desde el plano ontológico, se recurre en asuntos relacionados con los derechos de las personas con dis-

147 Número de Registro: 2001625. DeRECHO FUndAMENTAL A LA CULTURA. Localización: [TA]; 10a. Época; 1a. Sala; S.f.F. y su Gaceta; libro XII, septiembre de 2012, tomo 1; pág. 502. 1a. CGVII/2012 (10a.). Ver especialmente: Considerando quinto del amparo directo 11/2011, resuelto por la Primera Sala el dos de mayo de dos mil doce.

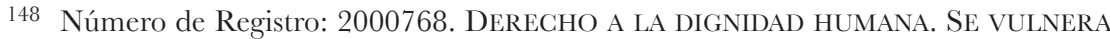
SI EN LA CUANTIFICACIÓN DE QUINQUENIOS A FAVOR DE UN EMPLEADO AL SERVICIO DEL GOBIERNO DEL ESTADO DE OAXACA SE APLICA LA CONVERSIÓN CONTENIDA EN EL Decreto Publicado en el Diario Oficial de la Federación EL 22 DE JUNiO DE 1992, POR EL QUE SE GREÓ LA NUEVA UNIDAD DEL SISTEMA MONETARIO NAGIONAL. Localización: [TA]; 10a. Época; T.C.C.; S.F.F. y su Gaceta; libro VIII, mayo de 2012, tomo 2; pág. 1856. XIII.T.A.3 L (10a.).

149 Número de Registro: 171297. SAlario MínIMO. El MARCO CONSTITUCiOnAL VIGENTE CONSTRIÑE AL LEGISLADOR ORDINARIO A NO GRAVAR LOS INGRESOS DE LOS TRABAJADORES QUE SOLAMENTE OBTIENEN ESE SALARIO. Localización: [J]; 9a. Época; 2a. Sala; S.f.F. y su Gaceta; tomo XXVI, septiembre de 2007; pág. 553. 2a./J. 172/2007. 
capacidad y los relativos a la procura existencial derivados de la interpretación del artículo 25 de la Constitución federal. A continuación, realizaré una propuesta sobre la categoría de persona y dignidad humana pensada desde la Constitución, a partir de las reflexiones sobre la interpretación que ha recibido de parte de los tribunales.

\section{CONCLUSIONES: HACIA UNA IMAGEN DE PERSONA HUMANA DESDE LA CONSTITUGIÓN MEXICANA}

La dignidad humana debe actuar como una premisa hermenéutica para la comprensión de los derechos fundamentales y dar sentido a los distintos fines del Estado constitucional, tales como la realización de la libertad y el desarrollo armónico de la persona. La reconstrucción de este principio se da en la modernidad, mediante su incorporación en las Constituciones de mitades del siglo XX, a partir de las tradiciones antigua, medieval, ilustrada y moderna. También es importante advertir el carácter multidisciplinar de este valor superior del ordenamiento, cuya comprensión no es suficiente mediante una visión reduccionista de las normas jurídicas. Por ello, algunos tribunales como el alemán han reconstruido la dignidad a partir de tres vertientes principales: fórmula de no instrumentalización, orden objetivo de valores e imagen del hombre. Esta última puede ser una interesante propuesta para la jurisprudencia mexicana. Las reformas en 2001 a los artículos 1o., último párrafo, y 2o. constitucionales, que interpretan y descifran a la dignidad humana a partir del valor de la autonomía y la igualdad, son importantes para entender el proceso de evolución expansiva que han tenido los derechos humanos.

Asimismo, es importante advertir que la jurisprudencia generada sobre dignidad humana en México se traduce en un primer plano, en la idea de igualdad y no discriminación, pregonando el valor de la autonomía de la persona. Esto es así, ya que el origen de la dignidad humana como premisa hermenéutica para expandir o ampliar el contenido esencial de los derechos humanos en la jurisprudencia mexicana data de 2007, por el tribunal constitucional mexicano se desarrolla mediante la comprensión de los derechos de las minorías, particularmente los derechos diferenciados de personas transexuales y homosexuales. Por este motivo, creo que es importante precisar que el juez mexicano ha cambiado de paradigma para incorporar una idea de persona humana incluyente y plural.

Esta obra está bajo una Licencia Creative Commons

Atribución-NoComercial-SinDerivar 4.0 Internacional, IIJ-UNAM.

Boletín Mexicano de Derecho Comparado, núm. 151, pp. 135-173. 
Precisamente, mediante el reconocimiento de los derechos de las minorías se alcanzan a reconocer grupos socialmente desfavorecidos que antes no figuraban en el constitucionalismo, y esta comprensión se ha realizado no desde el tradicional concepto de igualdad formal, e incluso político, sino a través de distintos planos de análisis, como el sociológico, político, filosófico y antropológico. Por ejemplo, cuando se resuelven los casos de las personas sexualmente diferenciadas, se invocan los valores de autonomía y dignidad de la persona, reconociendo desde el punto de vista filosófico la compatibilidad de su condición biológica con su proyecto de vida, cuestión que sin duda alguna pregona una idea antropológica neutral de persona, abierta y sujeta a los procesos científicos, relacionados con las tecnologías de manipulación del cuerpo humano, pero sobre todo, que desde el plano filosófico buscan la realización plena del ser humano.

Destacan igualmente en un segundo plano las decisiones del máximo tribunal mexicano, donde se invoca la dignidad humana en un plano ontológico en relación con el derecho al mínimo vital o procura existencial, desde asuntos de carácter fiscal y laboral, principalmente enfocados a proteger el salario mínimo. En clave hermenéutica, para la definición de dignidad humana en sentido ontológico y subjetivo existen precedentes que auxilian a comprender de manera más amplia la esencia y fin de los derechos humanos, pero la riqueza jurisprudencial generada a partir de la fórmula de no instrumentalización de la persona humana es mayor, al alcanzar un mayor número de precedentes judiciales.

Consideramos que debe incrementarse en la jurisprudencia mexicana el empleo de la fórmula de no instrumentalización de la persona humana a otras áreas distintas al derecho penal, tales como el derecho civil (conflictos sobre derecho al honor, contratos civiles), problemas como el aborto, suicidio asistido, derechos de la mujer, incluso derechos del niño (no instrumentalización del menor en juicios de convivencia) y derechos laborales (no instrumentalización del trabajador como mero factor de producción). En este contexto, aún queda mucho camino por recorrer. Quizá sea de gran valía revisar la interpretación que ha realizado la Corte Interamericana (vigente para los jueces mexicanos desde 2011) sobre dignidad de la persona en temáticas de integridad personal, ${ }^{150}$ derechos de

150 Corte IDH, caso Velásquez Rodríguez vs. Honduras, fondo, sentencia del 29 de julio de 1988, serie C, núm. 4, § 154, 156, 158 y 165; caso Caballero Delgado y Santana vs. Colombia, 
la mujer, ${ }^{151}$ vida privada (no discriminación), ${ }^{152}$ dignidad del embrión (fecundación in vitro), ${ }^{153}$ derechos del niño, ${ }^{154}$ personas con discapacidad, ${ }^{155}$ derechos de migrantes, ${ }^{156}$ derechos indígenas, ${ }^{157}$ y protección de la honra y dignidad. ${ }^{158}$ Aunque es sumamente criticable que estos precedentes estén circunscritos a la integridad de la persona, y se incorpore la idea de dignidad de manera indirecta, sería interesante formular nuevas concepciones a partir de las reflexiones del organismo internacional. ${ }^{159}$

fondo, sentencia del 8 de diciembre de 1995, serie C, núm. 22, § 53; caso Neira Alegría y otros vs. Perú. Fondo, sentencia del 19 de enero de 1995, serie C, núm. 20, § 86; caso de los "Niños de la Calle" (Villagrán Morales y otros) vs. Guatemala, fondo, sentencia del 19 de noviembre de 1999, serie C, núm. 63, § 164 y 166; caso del Penal Miguel Castro Castro vs. Perú, Fondo, reparaciones y costas, sentencia del 25 de noviembre de 2006, serie C, núm. 160, § 306.

151 Corte IDH, caso Fernández Ortega y otros vs. México, excepción preliminar, fondo, reparaciones y costas, sentencia del 30 de agosto de 2010, serie C, núm. 215, § 118; caso Rosendo Cantú y otra vs. México, excepción preliminar, fondo, reparaciones y costas, sentencia del 31 de agosto de 2010, serie C, núm. 216, § 108.

152 Corte IDH, caso Atala Riffo y Niñas vs. Chile, fondo, reparaciones y costas, sentencia del 24 de febrero de 2012, serie C, núm. 239, § 162.

153 Corte IDH, caso Artavia Murillo y otros (Fertilización in vitro) vs. Costa Rica, excepciones preliminares, fondo, reparaciones y costas sentencia del 28 noviembre de 2012, serie C, núm. 257, § 247.

154 Corte IDH, caso "Instituto de Reeducación del Menor" vs. Paraguay, excepciones preliminares, fondo, reparaciones y costas, sentencia del 2 de septiembre de 2004, serie C, núm. 112, § 159; caso de las Niñas Yean y Bosico vs. República Dominicana, excepciones preliminares, fondo, reparaciones y costas, sentencia del 8 de septiembre de 2005, serie C, núm. 130, § 179; caso Forneron e hija vs. Argentina, fondo, reparaciones y costas, sentencia del 27 de abril de 2012 serie $\mathrm{C}$, núm. 242, § 49.

155 Corte IDH, caso Furlan y Familiares vs. Argentina, excepciones preliminares, fondo, reparaciones y costas, sentencia del 31 de agosto de 2012 serie C, núm. 246, § 130.

156 Corte IDH, caso Nadege Dorzema y otros vs. República Dominicana, fondo, reparaciones y costas, sentencia del 24 de octubre de 2012, serie C, núm. 251, § 233; caso Vélez Loor vs. Panamá, excepciones preliminares, fondo, reparaciones y costas, sentencia del 23 de noviembre de 2010, serie C, núm. 218, § 100.

157 Corte IDH, caso Comunidad Indígena Takye Axa vs. Paraguay, fondo reparaciones y costas. sentencia del 17 de junio de 2005, serie C, núm. 125, § 162; caso Nadege Dorzema y otros vs. República Dominicana, fondo, reparaciones y costas, sentencia del 24 de octubre de 2012, serie C, núm. 251, § 154 .

158 Corte IDH, caso Manuel Cepeda Vargas vs. Colombia, excepciones preliminares, fondo, reparaciones y costas, sentencia del 26 de mayo de 2010, serie C, núm. 213, § 205.

159 Amezcua, Luis, "Algunos puntos relevantes sobre la dignidad humana en la jurisprudencia de la Corte Interamericana de Derechos Humanos", Revista Iberoamericana de Derecho Procesal Constitucional, núm. 8, 2007, pp. 339-355

Esta obra está bajo una Licencia Creative Commons

Atribución-NoComercial-SinDerivar 4.0 Internacional, IIJ-UNAM.

Boletín Mexicano de Derecho Comparado, núm. 151, pp. 135-173. 
El contenido esencial de la dignidad humana no debe quedar reducido al mero aspecto ontológico o una simple declaración ética, sino que debe ser parte de un sistema objetivo de valores constitucionales a partir del cual el ordenamiento jurídico en su conjunto adquiera sentido. La propuesta es que, a partir de un concepto mínimo de dignidad, los tribunales puedan reformular el contenido esencial de los derechos humanos a través de la hermenéutica constitucional empleando diversas técnicas que brinda el derecho comparado, tales como la fórmula de no instrumentalización de la persona humana, y explorar así nuevas temáticas, o bien enfocar desde otras perspectivas (género, derechos diferenciados, mínimo vital, etcétera) conflictos de cualquier materia (civil, mercantil, fiscal, etcétera) bajo un concepto abierto y dinámico de persona humana.

Finalmente, cabe concluir que todo proceso de construcción de una categoría como la dignidad e imagen de la persona humana desde la Constitución debe ser realizado bajo distintos horizontes de comprensión del fenómeno jurídico, tal y como he explicado en líneas anteriores. El desarrollo de nuevas tecnologías nos arroja dilemas éticos que deben ser resueltos a partir de una comprensión integral y holística del fenómeno en cuestión. Delimitar y circunscribir el tema de la dignidad humana al ámbito estrictamente jurídico nos dejaría fuera de la enorme riqueza conceptual de otras ciencias y áreas afines, que finalmente también ayudan a comprender e integrar armónicamente el derecho. 